\title{
The Use of Methods of Environmental Analysis and Ecotoxicological Tests in the Evaluation of Wastewater
}

\author{
Helena Zlámalová Gargošová, Milada Vávrová, Helena Doležalová \\ Weissmannová, Ludmila Mravcová, Lucie Vydrová and Libor Zouhar \\ Brno University of Technology, Faculty of Chemistry \\ Czech Republic
}

\section{Introduction}

The term "new" environmental pollutant covers all anthropogenic contaminants that have been released in the environment over the last few decades. Research into their fate and impact on the environment has started relatively recently. The group of new environmental pollutants consists of persistent organic pollutants (POPs) including DDT, polychlorinated biphenyls, polycyclic aromatic hydrocarbons and a wide range of organic pesticides. This group has recently been expanded with polybrominated flame retardants, drugs, detergents, and personal hygiene products. Chemicals, used everyday in homes, industry and agriculture, can enter the environment in wastewater. According to the United Nations Organization 884 million people do not have access to safe drinking water, and over 2.6 billion people do not have access to proper sanitation systems. On July 28, 2010, the UN General Assembly passed a resolution supporting water as a human right and urging governments and international organizations to address this important human right.

Interest in the presence of pharmaceuticals, personal care products, and endocrine disruptors in the environment has increased significantly over the last decade. Pharmaceuticals and synthetic musk compounds in personal care products (PPCPs), are groups of organic micropollutants which are routinely detected in surface water, ground water and even in drinking water (McClellan and Halde, 2010). Hundreds of tons of these compounds are dispensed in communities every year. PPCPs are regarded as being potentially hazardous compounds as some are ubiquitous, persistent and biologically active compounds with recognised endocrine disruption functions (Kasprzyk-Hordern et. al., 2002). Many pharmaceuticals, upon administration, are degraded in the body and may even become inactive, but others, often those applied externally, excreted or not absorbed fully, can leave the body in their active forms. (Roberts \&Thomas, 2006). The others only slightly transformed or even unchanged often conjugated to endogenous substrate (e.g. glucuronic acid, sulfuric acid, acetic acid to polar molecules. (Roberts and Thomas, 2006). These conjugates are easily cleaved during sewage treatment and, thus, several pharmaceutically active compounds (PhACs) are discharged almost unchanged from municipal sewage treatment plants (STPs) into the receiving waters (Heberer, 2002). The wide range of trace chemical contaminants persisting in municipal wastewater after conventional treatment 
includes inorganic compounds, heavy metals, persistent organic pollutants like endocrine disrupting compounds, pharmaceutically active compounds; personal care products (PPCPs), disinfection by-products and many other complex compounds persist through the waste water treatment process. As a result, terrestrial and aquatic organisms can be exposed to these compounds when treatment by-products are subsequently reintroduced into the broader environment. Exposure can be associated with effluents from waste water treatment plants (WWTPs) leach from landfills, and runoff or leach from land that has received applications of reclaimed waters and/or biosolids. Thus, a number of PPCPs are widely detected in water resources throughout the world (Edwards et al., 2009; Lapen et al., 2008; Fatta-Kassinos et al., 2010). From reasons mentioned above is very important to monitor large spectra of chemicals not only in biosolids, which represents inevitable by-products of WWTPs, but in reclaimed water from municipal wastewater treatment. Waste water treatments produces large amount of sewage sludges/biosolids. Part of them is after treatment process used as fertilizer (Jones-Lepp \& Stevens, 2006). The Sewage Sludge Directive 86/278/EEC seeks to encourage the use of sewage sludge in agriculture and to regulate its use in such a way as to prevent harmful effects on soil, vegetation, animals and man. On the other hand sludge could be posing a risk for environment they tends to concentrate heavy metals and organic but its, however, rich in nutrients such as nitrogen and phosphorous and contains valuable organic matter. Directive 86/278/EEC sets limit values for seven heavy metals, for some congeners of PCBs and AOX (Absorbable organic halides) other organic compounds and ecotoxicity tests arent' required The European Commission is currently assessing whether the current Directive should be reviewed - and if so, the extent of this review (Council directive, 1986).

In the 1980' and 90'the focus on the analysis of sewage sludge meanly deal with pathogens, inorganic (metals), polynuclear aromatic hydrocarbons (PAHs), polychlorinated biphenyls (PCBs) and polychlorinated dibenzo-p-dioxins and dibenzofurans (PCDD/Fs) (Alcock et al.; 1996 Eljarrat et al., 2001). In $21 \mathrm{TH}$ century analysis of these matrices is not target only for selected traditional analytes but new xenobiotics as pharmaceuticals and musk compounds in sewage sludge are reported (Herren \& Berset 2000; Zorita et al., 2009; McClellan \& Halde, 2010). Ecotoxicological evaluation of sewage sludge as integral part of environmental analysis started to appear in this century sparsely (Park et al. 2005, Domene et al., 2008). Chemicals analysis is integral part of water quality evaluation but to predict effect of this water or used sewage sludge on environment is necessary to use some other possibilities. Useful toll for this could be biotests. Global evaluation of wastewaters should include ecotoxicological tests to complete the chemical characterization. The integrated assessment of biological effects of wastewater discharges in the ecosystems is relevant and ecotoxicity tests are referred as extremely useful tools for the identification of environmental impacts (Mendonca et al., 2009).

\subsection{Pharmaceuticals}

Pharmaceuticals are biologically active substances. It is documented that drug production and consumption are increasing worldwide, both in human and veterinary medicine. The consequence of this trend is the increased input of these substances into the environment, where they can exist in their original or metabolized form and can have significant impacts on natural ecosystems (Halling-Sörensen, 1998). The hazardous source of pharmaceuticals represents agriculture, predominantly livestock production. Growth stimulants and antibiotics used as prophylaxis drugs entered ecosystem in faeces and urine as fertiliser 
without possibilities degradation on less active metabolites in WWTP (Koschorreck et al., 2002). Biodegradation in digestive system of animals it is possible, but not for all substance. In study (Halling-Sorensen et al., 1998; Hirsch et al., 1999) was demonstrate, that 30-90\% doses of antibiotics enter he environment in origin form. At the end Pharmaceuticals are specially target on elimination of pathogenic organisms, in this case they could decrease number of microorganisms in WWTP and affect treatment process of water treatment. Antibiotics were recently classified as a priority risk group due to their high toxicity to algae and bacteria at low concentrations and their potential to cause resistance amongst natural bacterial populations Hence, antibiotics in surface water have the potential to disrupt key bacterial cycles/processes critical to aquatic ecology (nitrification/denitrification) or agriculture (soil fertility) and animal production (rudimentary processes) (Watkinson et al., 2007; Watkinson et al. , 2009).

\begin{tabular}{|c|c|c|c|c|}
\hline & $\begin{array}{l}\text { Diclofenac } \\
\text { Sodium }\end{array}$ & $\begin{array}{l}\text { Ibuprophen } \\
\text { sodium }\end{array}$ & Ampicillin & Penicillin G \\
\hline CAS & $15307-79-6$ & $31121-93-4$ & $69-53-4$ & $61-33-6$ \\
\hline Physical state & $\begin{array}{l}\text { White or slightly } \\
\text { yellowish } \\
\text { crystalline } \\
\text { powder, slightly } \\
\text { hygroscopic } \\
\text { Sparingly soluble } \\
\text { in water, freely } \\
\text { soluble in } \\
\text { methanol. }\end{array}$ & $\begin{array}{l}\text { White crystalline } \\
\text { powder. } \\
\text { Sparingly } \\
\text { soluble in water, } \\
\text { freely soluble in } \\
\text { acetone, } \\
\text { methanol, ether. }\end{array}$ & $\begin{array}{l}\text { White powder, } \\
\text { slightly } \\
\text { hygroscopic. } \\
\text { Soluble in } \\
\text { water, insoluble } \\
\text { in alcohol, oils. }\end{array}$ & $\begin{array}{l}\text { White powder. } \\
\text { Soluble in water, } \\
\text { insoluble in } \\
\text { alcohol, various } \\
\text { oils and } \\
\text { paraffin's. }\end{array}$ \\
\hline $\begin{array}{c}\text { Molecular } \\
\text { weight } \\
\text { (g/mol) }\end{array}$ & 318.13 & 228.26 & 371.39 & 334.39 \\
\hline $\begin{array}{l}\text { Melting point } \\
\qquad\left({ }^{\circ} \mathrm{C}\right)\end{array}$ & $278-279$ & $75-78$ & 324.85 & 243.10 \\
\hline $\begin{array}{l}\text { Boiling point } \\
\left({ }^{\circ} \mathrm{C}\right) \text { at } 25^{\circ} \mathrm{C}\end{array}$ & 412.00 & 157.00 & 622.61 & 565.30 \\
\hline $\begin{array}{c}\text { Water } \\
\text { solubility } \\
\left(\mathrm{mg} \mathrm{l}^{-1}\right) \text { at } 25^{\circ} \mathrm{C}\end{array}$ & 50.00 & 57,90 & 439.30 & 210.40 \\
\hline $\begin{array}{l}\text { Henry's Law } \\
\text { Constant } \\
\left(\mathrm{atm} \cdot \mathrm{m}^{3} \cdot \mathrm{mol}^{-1}\right)\end{array}$ & $5.29 .10^{-9}$ & $1.23 .10^{-6}$ & $2.97 .10^{-16}$ & $1.88 .10^{-13}$ \\
\hline $\log \mathrm{K}_{\mathrm{OW}}$ & 1.56 & $\sim 1.00$ & 1.45 & 1.83 \\
\hline $\log \mathrm{K}_{\mathrm{OC}}$ & 2.92 & 2.59 & 2.73 & 2.63 \\
\hline
\end{tabular}

Table 1. Physico-chemical characteristics of pharmaceuticals 


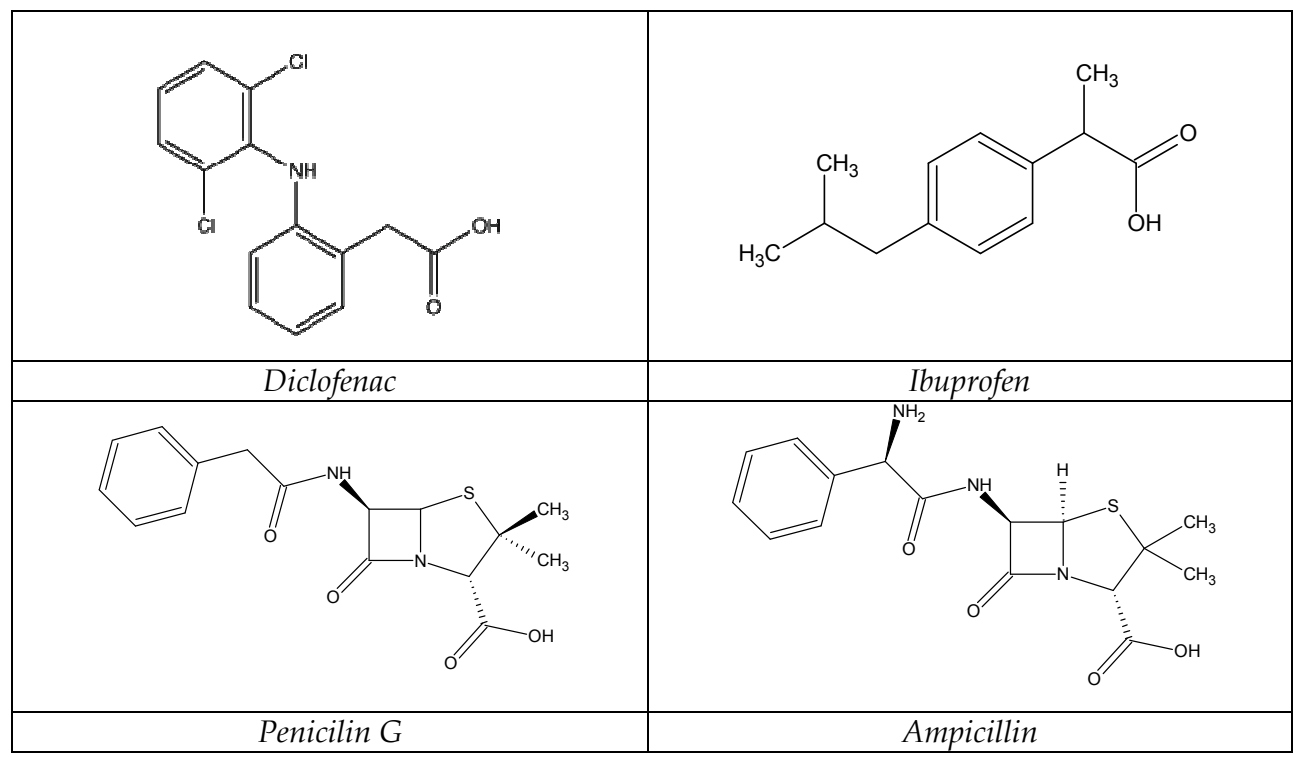

Fig. 1. Structural formulae of selected pharmaceuticals

Since pharmaceuticals are designed with the intention of performing a biological effect, this concept may be very important for these specific substances in terms of fate and effects toward non target organisms in the environment, even at low concentrations. The food chain of some organisms is affected and pathogenic organisms can develop their resistance against these substances. Another important problem is presented by the negative impact on bacterial microflora in biological cleaning processes. Pharmaceuticals are classified as the socalled "microcontaminants", which have been causing significant concern within the environmental area during past years. (Beausse 2004; Gómez et al. ,2006)

The most pharmaceuticlas are not completely removed in the wastewater treatment plant (Beausse, 2004; Gómez et al., 2006; Ramirez et al., 2007). They are partially eliminated by sorption to wastewater sludge or by biodegradadion. The elimination level differs in dependence on the substance type and process conditions. The elimination of antibiotics from the wastewater treatment plants can be also affected by sludge age. Non-steroidal antiinflammatory drugs (NSAIDs) with analgesic, antipyretic and anti-inflammatory effects such as diclofenac, ibuprophen and ketoprofen are one of the most widely used. It also belongs to the most frequently detected pharmaceuticals in the water-cycle in Europe. Antibiotics are the important group of the drugs affecting the environment. They are classified as biological, semisynthetic or synthetic substances. They are characterized by their selective toxicity against bacteria and they can be used to treat various infections. More than one hundred antibiotics are presently used. The primary classification of antibiotics is based on their effects and differentiates them on bactericidal and bacteriostatic. (Yang \& Carlson, 2003; Kay et al., 2005).

\subsection{Musk compounds}

Synthetic aromatic substances or musk compounds ("white musk") are lipophilic contaminants, with the ability to accumulate in the components of the environment. They 
belong to the group of priority persistent pollutants and may occur in the components of the environment and human tissue. Since they have potential carcinogenic properties, efforts are currently being made to limit or ban their use in many regions worldwide.

Generally, synthetic aromatic substances or musk compounds can be divided into 4 groups: linear musk compounds, macrocyclic musk compounds, polycyclic musk compounds and nitro musk compounds. The last two groups are used most frequently as fragrances in personal hygiene products (perfumes, cosmetics, soaps, and shampoo), cleaning and disinfection products, industrial cleaning products, air fresheners, etc.

Synthetic aromatic substances were launched on the market in the early 20th century. The volume of their production has significantly increased over the last 50 years (Luckenbach \& Epel, 2005). Galaxolide (HHCB) and Tonalide (AHTN) are examples of the most important musk compounds from the group of polycyclic compounds. Musk xylene, musk ketone and musk ambrette are well-known nitro musk compounds. The production of nitro musk compounds (i.e. compounds containing one or more nitro groups in a molecule) that are generally included in a group of substances posing a risk to the environment has decreased over the last years. By contrast, the production of polycyclic synthetic aromatic substances that are less toxic has increased and these substances are used in an abundant manner as additives in many products such as soaps, shampoos, deodorants, body lotions, perfumes, cleaning and disinfecting agents, air fresheners, industrial cleaning agents, etc. Unlike nitro

\begin{tabular}{|c|c|c|c|c|}
\hline & $\begin{array}{l}\text { Tonalide } \\
\text { (AHTN, } \\
\text { Fixolide) }\end{array}$ & $\begin{array}{c}\text { Galaxolide } \\
\text { (HHCB, } \\
\text { Abbalide) }\end{array}$ & Musk ketone & Musk xylene \\
\hline CAS & 1506-02-1 & 1222-05-5 & $81-14-1$ & $81-15-2$ \\
\hline Physical state & $\begin{array}{l}\text { Soluble in } \\
\text { alcohol, oils, } \\
\text { white solid } \\
\text { crystal }\end{array}$ & $\begin{array}{l}\text { Viscous liquid, } \\
\text { No colour and } \\
\text { stabile liquid }\end{array}$ & $\begin{array}{l}\text { Soluble in } \\
\text { alcohol, } \\
\text { various oils, } \\
\text { pale yellow } \\
\text { crystals }\end{array}$ & $\begin{array}{l}\text { Soluble in } \\
\text { alcohol, oils, } \\
\text { pale yellow } \\
\text { crystals or fine } \\
\text { crystalline } \\
\text { powder }\end{array}$ \\
\hline $\begin{array}{c}\text { Molecular } \\
\text { weight } \\
\text { (g/mol) }\end{array}$ & 258.41 & 258.39 & 294.27 & 297.27 \\
\hline $\begin{array}{l}\text { Melting point } \\
\left({ }^{\circ} \mathrm{C}\right)\end{array}$ & 104.26 & 104.26 & 241.07 & 245.65 \\
\hline $\begin{array}{l}\text { Boiling point } \\
\left({ }^{\circ} \mathrm{C}\right) \text { at } 25^{\circ} \mathrm{C}\end{array}$ & 325.92 & 325.92 & 560.94 & 570.75 \\
\hline $\begin{array}{c}\text { Water } \\
\text { solubility (mg } \\
\left.\mathrm{l}^{-1}\right) \text { at } 25^{\circ} \mathrm{C}\end{array}$ & 0.24 & 0.21 & 0.46 & 0.15 \\
\hline $\begin{array}{l}\text { Henry's Law } \\
\text { Constant } \\
\left(\mathrm{atm} \cdot \mathrm{m}^{3} \cdot \mathrm{mol}^{-}\right. \\
1)\end{array}$ & $2.28 .10^{-4}$ & $2.57 .10^{-4}$ & $1.33 .10^{-19}$ & $3.15 .10^{-17}$ \\
\hline Log $K_{\mathrm{OW}}$ & 5.70 & 5.90 & 4.30 & 4.90 \\
\hline Log $K_{O C}$ & 3.72 & 3.72 & 3.58 & 3.58 \\
\hline
\end{tabular}

Table 2. Physico-chemical characteristics of musk compounds 


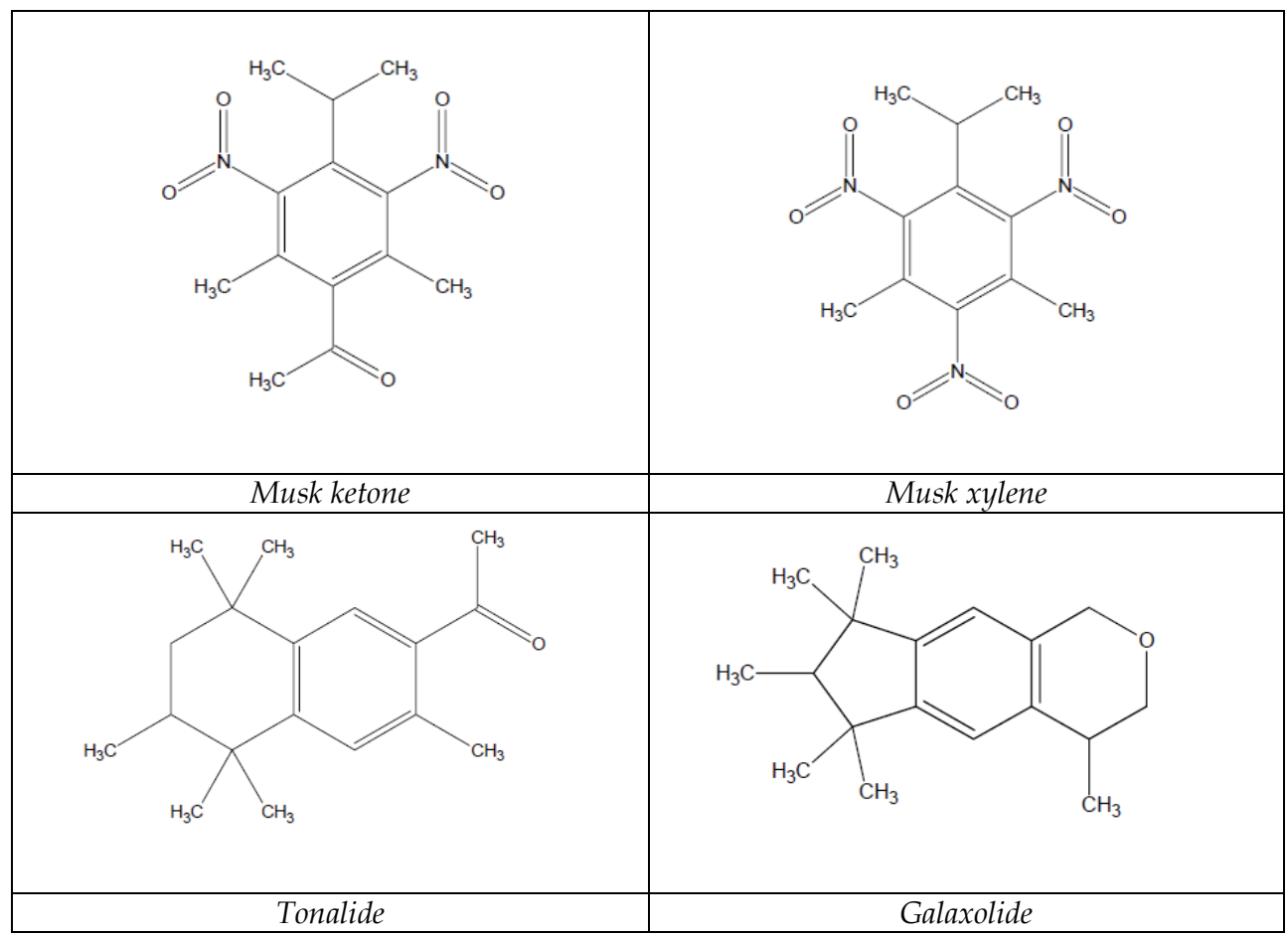

Fig. 2. Structural formulae of selected musk compounds

musk compounds, polycyclic musk compounds are more resistant against light and bases, and bind to fabrics quite easily. They are therefore used in cosmetic products and detergents more frequently. Logically, the reduced production of nitro musk compounds resulted in the increased production of polycyclic substances.

Synthetic aromatic substances are lipophilic, persistent organic compounds that show bioaccumulation abilities in the aquatic ecosystem. They were detected in the samples of air and dust collected in self-contained premises (Regueiro et al., 2009). A number of studies revealed the presence of musk compounds in the tissues of aquatic animals and also in human tissues. Musk compounds were also detected in fat tissue, human milk and blood plasma (Lignell et al., 2008).

The recent studies provided the presence of musk compounds in abiotic and biotic matrices. After their application the AHTN and HHCB are generally transported to wastewater treatment plants via industrial and municipal wastewaters (Fromme et al. 2001; Valdersnes et al. 2006, Wombacher et al. 2009). The various concentrations of the polycyclic musks have been determined in sewage treatment plants (on influent and effluent), surface waters, sediment in varies region of Europe and their concentration in aquatic ecosystems is highly depended on the distance from wastewater treatment plants. These toxic compounds are now widely found in variety of biota in the many regions in the world and its typical organism (Tanabe 2005; Nakata et al. 2007). The potential impact of polycyclic musk compounds were studied in relation to biodegradation, bioconcentration, determination of their concentrations in environmental matrixes (Bester 2009; Onesios et al. 2009; Lee et al. 2010; Sumner et al. 2010). 


\section{Environmental analysis}

The analysis of organic pollutants and the preparation of other samples required for the analysis start with the concentration of an analytes which can be achieved by using different methods, for example by liquid-liquid extraction, solid phase extraction, purge \& trap, headspace or other techniques that may be time demanding and require sophisticated instruments and organic solvents.

The solid-phase microextraction method (SPME) is a simple and efficient sorptiondesorption technique allowing the analytes to be concentrated. It is based on the exposure of a small amount of sorbent (extraction phase) to an excess of a sample. The goal of most SPME procedures used for sample preparation prior to analysis is to obtain a particular analytes in a sufficient detectable amount without any unwanted admixtures. In the case of SPME, analytes bind to a fibre until the steady state is reached. The SPME method is used in both qualitative and quantitative analysis. The accuracy and precision of the results is affected by a number of factors. The SPME method provides linear calibration dependence in a wide range of concentrations. The proper choice of fibre will ensure reproducible results even at low levels of analytes.

SPE is typically performed manually, but there are some significant disadvantages with this approach (Fatta et al., 2007):

- manual (off-line) SPE is time-consuming as well as labor-intensive and costly, which compromises productivity;

- $\quad$ exposure to hazardous or infectious matrices (such as sewage) involves safety issues; and,

- the recovery of the analytes can vary from batch to batch, causing reproducibility problems.

- direct injection of untreated samples;

- automatic sample clean-up and/or analyte enrichment;

- elimination of conventional manual sample pretreatment

- steps;

- faster procedures;

- $\quad$ methods are less prone to errors, resulting in Berger reproducibility;

- reduction of health risks; and,

- $\quad$ samples can be run unattended (e.g., overnight or over the weekend).

The methods of high performance liquid chromatography (HPLC) with diode-array detection (DAD) or mass detector (MS) are also the widely utilizing analytical method (HPLC-DAD, HPLC-MS) for determination of pharmaceuticals and musk compounds. The method gas chromatography with mass detector (GC-MS) or gas chromatography with atomic emission detector (GC-AED) detect compound with excellent sensitivity.

\subsection{Sampling area}

The first one is large-scale wastewater treatment plant of the City of Brno (catchment region for a population of 500,000 people). There is municipal waste water treated. This facility was launched in 1961 as classic two-stage plant with anaerobic sludge stabilization. In the period between 2001 - 2003 the overall reconstruction and extension of the WWTP was realized with the main objective to meet the treated wastewater effluent limits set by Czech and European standards and regulations, and to ensure sufficient capacity of the facility to accommodate the growing demand of the city of Brno with almost 500 thousand of 
inhabitants and several industrial facilities, but also of increasing number of the surrounding agglomerations successively connecting to the Brno sewerage system. Nowadays, the technology in WWTP Brno-Modrice corresponds to the EU parameters. The second WWTP collects waste water from laboratories and from research workplaces is there collected. The municipal WWTP uses technology of anaerobic stabilization of sewage sludges. This closing step is included to minimalize decomposition of residual organic material and mainly to eliminate pathogenic organisms. Three previous steps of water treatment include mechanical removing of settled elements, chemical treatment defosfatation and denitrification in anaerobic tank. Follow biological treatment in activated tank, under oxygen conditions. Secondary settlement tank is final tank where is activated sewage sludge settled and separated out from treated water. The technology of small local WWTP located on the grounds of the University of Veterinary and Pharmaceutical Sciences in Brno involves aeration in activated tank, followed with separation of activated sewage sludges. Water is sanitized with chlorine and sewage sludges are thermic stabilised (125 $\left.{ }^{\circ} \mathrm{C} / 35 \mathrm{~min}\right)$. Then water enters to communal sewerage system. The amber glass sample bottles were used for this collection. The samples were processed immediately or stored in a refrigerator till the following day. If necessary, the samples were filtered to remove rough impurities.

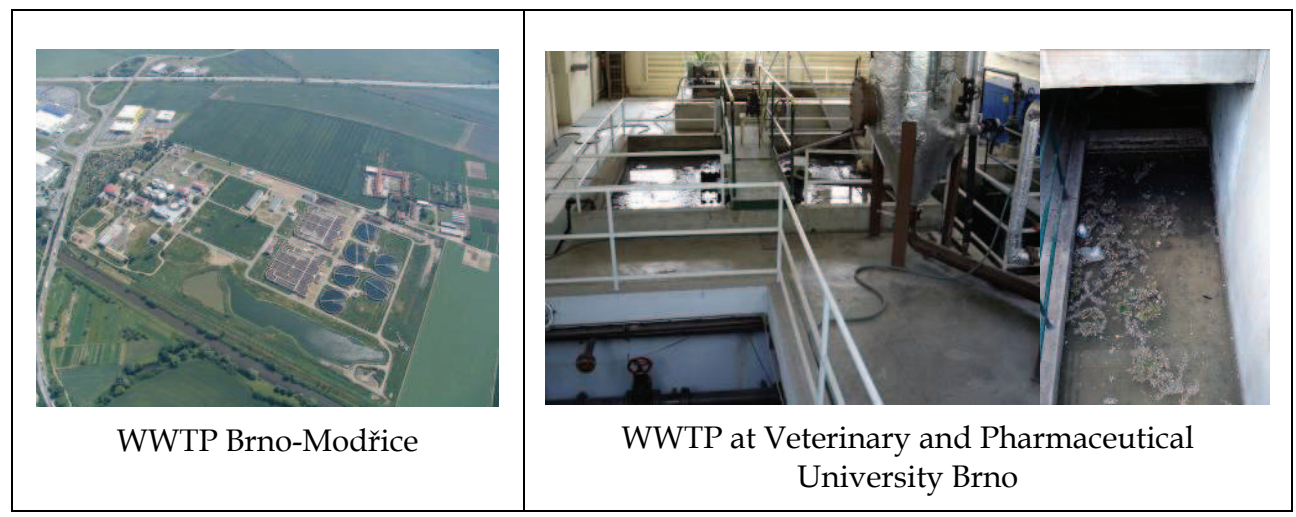

Fig. 3. The sampling localities

Wastewater samples have been collected from the two wastewater treatment plant municipal WWTP Brno-Modřice and WWTP at Veterinary and Pharmaceutical University Brno in one-day intervals and from in seven-days intervals. The sampling of waste water and sludge for experiments were from the WWTP inlet, outlet and lagoon (pond) from reason of comparing.

\subsection{The analysis of pharmaceuticals}

The application of advanced measurement technologies (e.g., gas chromatography with mass spectrometry (GC-MS) and GC with tandem MS (GC-MS2) or liquid chromatography with MS (LC-MS) and LC with tandem MS (LC-MS2)) to environmental analysis has allowed the determination of a broader range of compounds, including pharmaceuticals, and has therefore permitted more comprehensive assessment of environmental contaminants. LC-MS2 is becoming more commonly used in pharmaceuticals analysis 
because of its high sensitivity and its ability to confirm compounds (as compared with conventional LC with ultraviolet (UV) or fluorimetric detection). LC-MS2 allows separation and detection of compounds having the same molecular mass but different product ions, even if they co-elute. MS2 detection is therefore preferred for increased analytical sensitivity and selectivity in complex matrices, such as wastewaters. (Kot-Wasik et al., 2007).

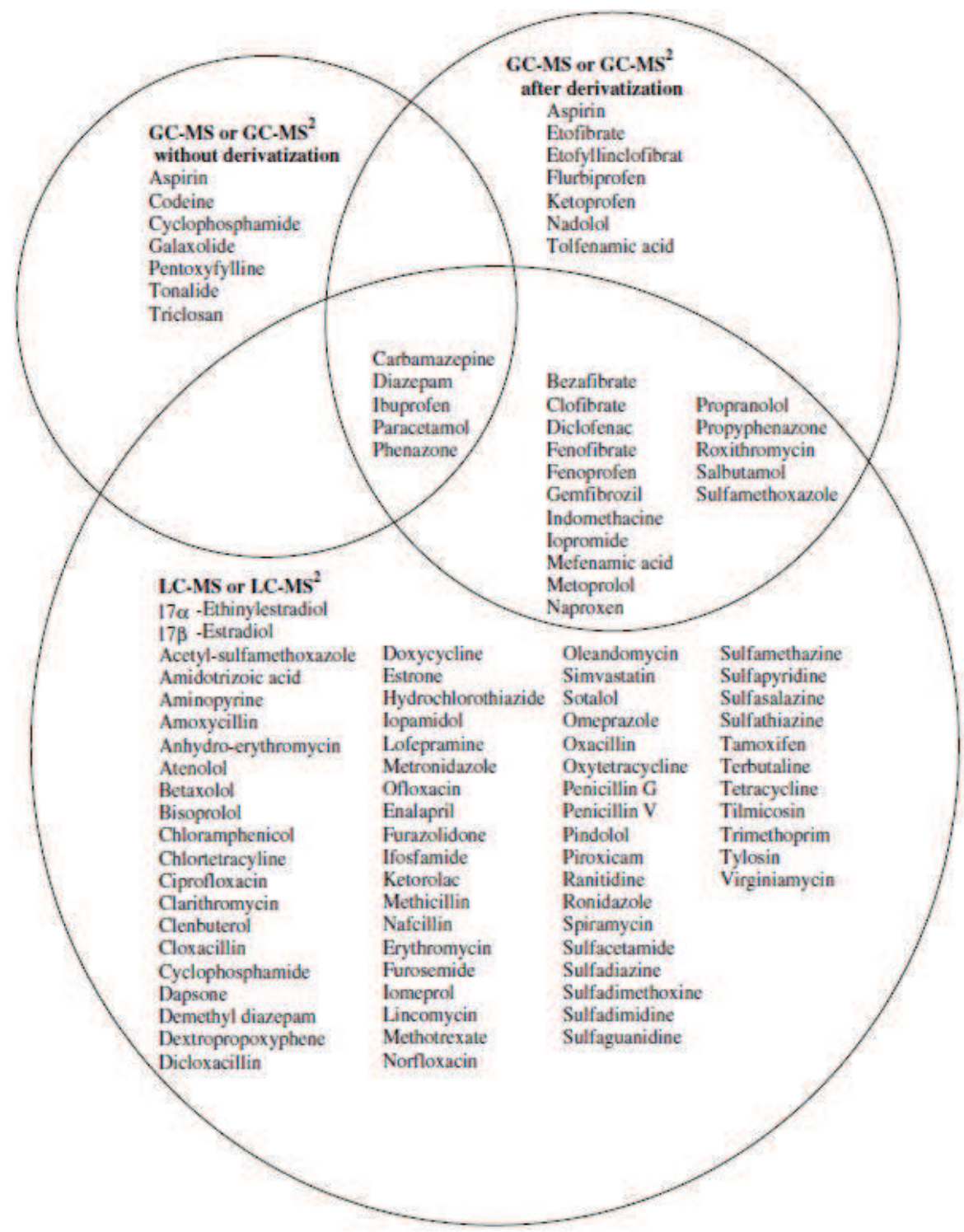

Fig. 4. Analytical methods applied for the most common pharmaceuticals in water and wastewater (Fatta et al.,2007) 
Solid phase extraction (SPE) was employed as the separation method for isolation of given pharmaceuticals and high performance liquid chromatography (HPLC) with diode-array detection was used for their determination. The optimised and validation method was used to model samples of water. Obtained results were evaluated and their interpretation was done.

Several different columns were tested for diclofenac (Nonsteroidal anti-inflammatory substances - NSAIDs). Oasis HLB is column with hydrophilic-lipophilic balance. It includes copolymer divinylbenzen/N-vinylpyrrolidin. Often they are used for solid phase extraction of pharmaceuticals.

Sorbent with polymerization bonded oktadecyl phase is in ENVI-18. These columns are employed especially for environment. LC SAX was last tried column. It is ion exchanger column with polymerization bonded quaternary amine.

From the Table 3 it is implied, that the respective procedure for SPE is acceptable for diclofenac when using Oasis HLB and ENVI-18 cartridges. The Oasis HLB column was selected as the suitable one, due to highest yields of diclofenac from the cartridges tested. To find the optimal procedure SPE for both drugs, other SPE courses were tested on Oasis HLB columns.

\begin{tabular}{|c|c|c|c|}
\hline SPE & $\begin{array}{c}\text { Original diclofenac } \\
\text { concentration } \\
(\mathrm{mg} / \mathrm{ml})\end{array}$ & $\begin{array}{c}\text { Final concentration of } \\
\text { diclofenac } \\
(\mathrm{mg} / \mathrm{ml})\end{array}$ & $\begin{array}{c}\text { Diclofenac } \\
\text { recovery } \\
\%\end{array}$ \\
\hline Oasis HLB & 0.0150 & 0.0042 & 28.04 \\
\hline ENVI-18 & 0.0150 & 0.0036 & 24.23 \\
\hline LC-SAX & 0.0150 & $2.37 .10-5$ & 0.16 \\
\hline
\end{tabular}

Table 3. Recovery on SPE columns HLB when testing various procedures

The pharmaceutical Diclofenac and Ibuprofene were determined at inflow and outflow of WWTP Brno-Modřice. The determined concentration of ibuprophene at inflow was 1018.14 $\mathrm{ng} / \mathrm{l}$ and at outflow $195.97 \mathrm{ng} / \mathrm{l}$. The efficiency of water treatment process for Ibuprofene was $80 \%$. The aim of this work was to develop both a suitable analytic method for analytes isolation from a given matrix and an optimal technique for identification and determination of analgetics residues in waters. Solid phase extraction (SPE) was employed as the separation method for isolation of given pharmaceuticals and high performance liquid chromatography (HPLC) with diode-array detection was used for their determination. The optimized method was used to model samples of water. Obtained results were evaluated and their interpretation was done

The aim of this work was to develop both a suitable analytic method for analytes isolation from a given matrix and an optimal technique for identification and determination of analgetics residues in waters. Solid phase extraction (SPE) was employed as the separation method for isolation of given pharmaceuticals and high performance liquid chromatography (HPLC) with diode-array detection was used for their determination. The optimized method was used to model samples of water. Obtained results were evaluated and their interpretation was done. 


\begin{tabular}{|c|c|c|c|c|c|c|}
\hline Analytes & $\mathrm{N}$ & 1 & 2 & 3 & 4 & 5 \\
\hline & \multicolumn{6}{|c|}{ Inflow } \\
\hline \multirow{7}{*}{ Diclofenac } & I1 & NQ & NQ & NQ & NQ & NQ \\
\hline & $\mathrm{I} 2$ & 1363.16 & 84.40 & 1874.95 & 2511.63 & 1970.58 \\
\hline & I3 & 1669.12 & $<\mathrm{LOD}$ & 2139.03 & 2439.98 & 2148.06 \\
\hline & \multicolumn{6}{|c|}{ Outflow } \\
\hline & O1 & NQ & NQ & NQ & NQ & NQ \\
\hline & $\mathrm{O} 2$ & 5.69 & NQ & NQ & NQ & NQ \\
\hline & $\mathrm{O} 3$ & 9.29 & NQ & NQ & NQ & NQ \\
\hline \multirow{8}{*}{ Ibuprophene } & \multicolumn{6}{|c|}{ Inflow } \\
\hline & I1 & NQ & NQ & 503.78 & 2229.30 & 1170.20 \\
\hline & $\mathrm{I} 2$ & NQ & NQ & 272.50 & 1164.81 & 188.08 \\
\hline & I3 & NQ & NQ & 1271.06 & 193.30 & 432.21 \\
\hline & \multicolumn{6}{|c|}{ Outflow } \\
\hline & O1 & NQ & NQ & 222.70 & 212.41 & 69.29 \\
\hline & $\mathrm{O} 2$ & NQ & NQ & 275.19 & 181.85 & 153.38 \\
\hline & O3 & NQ & NQ & 155.22 & 124.58 & 369.10 \\
\hline
\end{tabular}

Table 4. The determined concentration of selected pharmaceuticals in waste water on inflow of WWTP Brno-Modřice (ng/l, n=10)

\subsection{The analysis of musk compounds}

In view of the physicochemical properties of musk compounds, most common analytical methods include separation by gas chromatography (GC) followed by online mass spectrometry (MS) Gas chromatography shows lowdetection limits, high selec tivity and sensitivity for determination of musk compounds.

Developments in the determination of synthetic musk fragrances in environmental matrices have been widely reviewed by A.M. Peck, 2006.

Traditional and worldwide used musk compounds Galaxolide ${ }^{\circledR}$, Tonalide ${ }^{\circledR}$, Musk xylene and Musk ketone were analysed. Samples were taken from the in influent, effluent and small pond in the WWTP Brno-Modřice municipal waste water treatment plant. Musk xylene was surprisingly found as the dominating compound, followed by Galaxolide, Tonalide and Musk ketone.

Head-space SPME with PDMS/DVB 65- $\mu$ m fibre was used for the isolation of musk compounds from real waste water samples. Then the SPME was removed and sorbed compounds were immediately desorbed in the injector of GC/MS system. Mass spectrometer was operated in SIM mode list of target ions and qualifiers for traditional musks shows Table 1, those for Czech fragrances presents Table 2. External standard method and standard addition method were utilized for quantization; recovery of the whole analytical process was controlled by deuterated standards (Musk xylene D15, Tonalide D3). During optimization, several real samples were also measured. It was found that the sample matrix had a significant negative effect on the determination of all analytes before ultrafiltration. HHCB and AHTN could only be detected in undiluted sample; however, after the standard addition, their response in the undiluted sample decreased. It was therefore decided to dilute samples at a ratio of 1:5 while maintaining the total volume of $14 \mathrm{ml}$. Distilled water was used for dilution. At this dilution and submersion, AMB and MK 
behaved as expected, showing the increasing response to the standard addition. In this case, it was decided to increase the dilution ratio to 1:10 and switch to the headspace. Thanks to the high concentrations of HHCB and AHTN in the undiluted sample, it was possible to employ greater dilution for the assay of HHCB and AHTN in the real sample.

Samples after ultrafiltration were not as difficult to analyse as samples before ultrafiltration.

\begin{tabular}{ccccccc}
\hline & \multicolumn{2}{c}{$\begin{array}{c}\text { Galaxolid } \\
\text { Sample }\end{array}$} & \multicolumn{2}{c}{$\begin{array}{c}\text { Tonalid } \\
(\text { AHTN })\end{array}$} & \multicolumn{2}{c}{$\begin{array}{c}\text { Musk ketone } \\
(\mathrm{MK})\end{array}$} \\
\cline { 2 - 7 } & $\begin{array}{c}\text { Inflow } \\
(\mathrm{ng} / \mathrm{ml})\end{array}$ & $\begin{array}{c}\text { Outflow } \\
(\mathrm{ng} / \mathrm{ml})\end{array}$ & $\begin{array}{c}\text { Inflow } \\
(\mathrm{ng} / \mathrm{ml})\end{array}$ & $\begin{array}{c}\text { Outflow } \\
(\mathrm{ng} / \mathrm{ml})\end{array}$ & $\begin{array}{c}\text { Inflow } \\
(\mathrm{ng} / \mathrm{ml})\end{array}$ & $\begin{array}{c}\text { Outflow } \\
(\mathrm{ng} / \mathrm{ml})\end{array}$ \\
\hline 1 & 187.7 & 0.66 & 24.64 & 0.179 & 2.28 & 0.082 \\
2 & 575.1 & $\mathrm{NQ}$ & 141.40 & 0.220 & 0.74 & 0.010 \\
3 & 54.1 & 1.84 & 33.32 & 0.695 & 2.56 & 0.020 \\
4 & 213.3 & 0.56 & 33.69 & 0.231 & $\mathrm{ND}$ & $\mathrm{ND}$ \\
5 & 31.1 & 0.55 & 12.80 & 0.811 & $\mathrm{ND}$ & $\mathrm{ND}$ \\
6 & 210.8 & 1.74 & 15.86 & 0.736 & $\mathrm{ND}$ & $\mathrm{ND}$ \\
7 & 86.7 & 0.67 & 5.19 & 0.172 & $\mathrm{ND}$ & $\mathrm{NQ}$ \\
8 & 50.1 & 0.50 & 10.62 & 0.156 & $\mathrm{ND}$ & $\mathrm{ND}$ \\
9 & 772.0 & 0.57 & 57.56 & 0.145 & $\mathrm{ND}$ & $\mathrm{NQ}$ \\
10 & 77.6 & 0.52 & 12.31 & 0.151 & $\mathrm{ND}$ & $\mathrm{NQ}$ \\
Mean & 225.9 & 0.85 & 34.74 & 0.350 & 1.860 & 0.037 \\
\hline
\end{tabular}

Table 5. The levels of analytes detected in samples,

(inflow $=$ before ultrafiltration, outflow $=$ after ultrafiltration $(n=10)$ )

As seen in Table 5 the highest levels were observed for HHCB in samples before ultrafiltration where the maximum level was $772.0 \mathrm{ng} / \mathrm{ml}$ whereas the lowest level was $31.1 \mathrm{ng} / \mathrm{ml}$. The levels in samples collected at the outflow were low. Maximum concentrations were observed in samples before ultrafiltration where the maximum estimated concentration was $141.40 \mathrm{ng} / \mathrm{ml}$. The minimum concentration in samples before ultrafiltration was $5.19 \mathrm{ng} / \mathrm{ml}$. The levels of AHTN in samples after ultrafiltration varied in a range of $0.811-0.145 \mathrm{ng} / \mathrm{ml}$.

Musk ketone (MK) was found in the inflow only during first three days of analysis. Its respective levels varied in a range of $0.74-2.062 \mathrm{ng} / \mathrm{ml}$. The performance of elimination of three monitored analytes reached $99 \%$. The performance for HHCB varied in a range of $96.60-99.93 \%$, for AHTN in a range of $93.66-99.84 \%$, and for MK in a range of $96.43-99.23 \%$.

The flow of wastewater in the ultrafiltration step varied in a range of 160-300 $\mathrm{l} / \mathrm{h}$. The facility is operated $10 \mathrm{hrs}$ a day on working days. The annual balance is based on 253 days. The mean flow of wastewater through the ultrafiltration step is approximately $230 \mathrm{l} / \mathrm{h}$. The discharge into the municipal sewer system is important, i.e. water that flows to the wastewater treatment plant. For better clarity, the amounts of analytes that enter the ultrafiltration step are also provided. All values are recalculated to the mean flow of $230 \mathrm{l} / \mathrm{h}$. Musk compounds are widely used as fragrances in cosmetic industry and its related fields. Due to their massive use over the last few decades, they are currently being detected in the majority of components of the environment. The first step to assay musk substances is to optimize the procedures of the isolation, identification, and quantification of individual 


\begin{tabular}{|c|c|c|c|c|c|c|c|c|c|c|c|c|}
\hline \multirow{3}{*}{$\mathrm{N}$} & \multicolumn{12}{|c|}{ Compound concentration (ng. $\mathrm{l}^{-1}$ ) } \\
\hline & \multicolumn{3}{|c|}{$\begin{array}{l}\text { Galaxolide } \\
\text { (HHCB) }\end{array}$} & \multicolumn{3}{|c|}{$\begin{array}{l}\text { Tonalide } \\
\text { (AHTN) }\end{array}$} & \multicolumn{3}{|c|}{$\begin{array}{c}\text { Musk xylene } \\
(\mathrm{MX})\end{array}$} & \multicolumn{3}{|c|}{$\begin{array}{l}\text { Musk ketone } \\
(\mathrm{MK})\end{array}$} \\
\hline & Inflow & Outflow & Pond & Inflow & Outflow & Pond & Inflow & Outflow & Pond & Inflow & Outflow & Pond \\
\hline 1 & 921 & 530 & 71 & 262 & 80 & 37 & 1223 & 955 & 972 & 56 & 47 & 71 \\
\hline 2 & 996 & 504 & 107 & 248 & 120 & 47 & 961 & 697 & 592 & 57 & 33 & 34 \\
\hline 3 & 762 & 646 & 111 & 194 & 180 & 56 & 1019 & 688 & 543 & 60 & 54 & 34 \\
\hline 4 & 739 & 528 & 101 & 192 & 132 & 56 & 1100 & 558 & 417 & 56 & 49 & 49 \\
\hline 5 & 880 & 858 & 149 & 217 & 170 & 66 & 1135 & 1491 & 686 & 58 & 54 & 27 \\
\hline
\end{tabular}

Table 6. Concentrations of traditional musks in Brno-Modřice WWTP $(n=10)$

analytes investigated. Great efforts during method optimization have been made to develop an efficient method that would be not time-consuming; eliminate possible errors during the entire procedure; and prevent the pollution of the external environment. Samples of wastewater collected at a cosmetic company before and after the ultrafiltration step were analysed using the SPME method (solid phase microextraction), followed by GC/MS (gas chromatography combined with mass spectrometry) as an end-point. The results are summarized in the following points:

- Analytes were determined in real samples using the SPME method and GC/MS as an analytical end-point. All samples collected before ultrafiltration contained HHCB and AHTN. Concentrations of HHCB and AHTN varied in a range of 31.1-772 $\mathrm{ng} / \mathrm{ml}$ and $5.2-141.4 \mathrm{ng} / \mathrm{ml}$, respectively. The levels of musk ketone in wastewater flowing to the ultrafiltration step varied in a range of $0.74-2.56 \mathrm{ng} / \mathrm{ml}$

- All samples of wastewater flowing from the ultrafiltration step contained AHTN at levels that ranged from 0.15 to $0.81 \mathrm{ng} / \mathrm{ml}$. HHCB was detected in almost all samples of wastewater (except for one) collected after the ultrafiltration step. The levels of HHCB varied in a range of $0.52-1.84 \mathrm{ng} / \mathrm{ml}$. MK was found in wastewater before the ultrafiltration step only 3 times. Its levels varied in a range of $0.01-0.08 \mathrm{ng} / \mathrm{ml}$.

- The calculation assumes 253 working days in 2010 to estimate the amount of discharged substances per year, with 20 days for every month. The amount of analytes is as follows: HHCB - $131.42 \mathrm{~kg}$ per year, $10.39 \mathrm{~kg}$ per month; AHTN - $20.21 \mathrm{~kg}$ per year, 1.60 $\mathrm{kg}$ per month; MK - $1.08 \mathrm{~kg}$ per year, $0.09 \mathrm{~kg}$ per month.

- Quantities of individual monitored musk compounds discharged were assessed in the same manner as in the previous point. The amount of discharged analytes is as follows: HHCB - $1.04 \mathrm{~kg}$ per year, $0.08 \mathrm{~kg}$ per month; AHTN - $0.20 \mathrm{~kg}$ per year, $0.02 \mathrm{~kg}$ per month; MK - $0.02 \mathrm{~kg}$ per year and $1.70 \mathrm{~g}$ per month. The efficiency of ultrafiltration employed to remove musk substances ranged from 96 to $99 \%$ in this particular case.

Although the efficiency of ultrafiltration is high, the respective analytes are still present in the wastewater that flows to the wastewater treatment plant.

\section{Environmental toxicology}

Environmental toxicology or ecotoxicology deals with potentially harmful effects on organisms of countless man-made chemicals and wastes released into biosphere Ecotoxicity tests, biotests, bioassays are the only way how to find out experimentally ecotoxicological characteristic of chemicals, hazardous wastes and other various matrices. Bioassays could give answer on following questions: 
- $\quad$ interaction between the substances (additive, synergistic, antagonistic etc)

- $\quad$ toxic effect after degradation and transformation of products

- $\quad$ quantity of the bioavailable chemicals

- effects on biota.

Testing system is exposed to various concentration of tested substance at exactly defined conditions (Park, et al., 2005). Contrary of the chemical analysis the tests are not able to identify the xenobiotics in the environment, on the other hand their advantage consist in prediction of effect on testing biological material. Advantages of biotests are also unquestionable. There are able to characterize hazard of xenobiotics in environment contrary to chemical analysis, which is able xenobiotics only identify and quantify. In addition in ecosystem hazardous compounds no exist separately but in various combinations wit mixture toxicity and environmental impact (Hoffmann, 2003). Biotest could be classified from various points of view. Standard and alternative test are the most basic classification. Standard toxicity tests are recommended by different international organizations such as ISO, EPA, OECD. The necessity to screen many samples for toxicity have lead to the increasing application of rapid miniaturized toxicity tests that are also called microbiotests, alternative assays, small-scale tests, microtests or second generation biotests. A microbiotest or alternative assay can be defined as involving the exposure of a unicellular or small multicellular organism to a liquid sample in order to measure a specific effect. Alternative toxicity tests have attractive features in comparison to standard toxicity tests; high cost efficiency, modest time and laboratory space requirements, possibility to test many samples at once, low sample volume requirements, (Blaise, 1991; Rojíćková, 1998). According to exposure time are the acute, semi-chronic and chronic tests used. The tests could be classified as terrestrial or aquatic. The aquatic tests use water solution of tested compounds or water leaches of tested matrices. In the terrestrial tests are testing organisms in direct contact with tested matrices. The selection of biotests used for toxicity assessment depends on the type of information that is required, the state, physical and chemical features of a sample or substance investigated and on sensitivity and relevance of a test species. However, if only one single test is used, the estimated toxicity would reflect the sensitivity of that test only, with a risk for underestimation of the potential toxicity for that particular substance with regard to the ecosystem. The use of a battery of biotests, representing differences in sensitivity of test organisms from various trophic levels is recommended to prevent this situation. Therefore it is important to identify potential toxins and understand the magnitude of their impact on different terrestrial and aquatic ecosystems (Schowanek et al., 2004)

\subsection{Procedure of ecotoxicity test}

The aim of the ecotoxicological tests is the determination of effective concentration (EC), eventually lethal concentration (LC) or inhibition concentratin (IC) to assess the effect of chemical compound, water wastes and leaches of various materials (sediments, soils, wastes etc.) on aquatic and terrestrial organisms. From this date the ecotoxicological impact to aquatic and terrestrial ecosystems can be also derived. These concentrations of tested compounds cause the mortality of $50 \%$ testing organisms or $50 \%$ inhibition growth rate in relation to control tests. Lower values of $\mathrm{LC}(\mathrm{EC}, \mathrm{IC}) 50$ indicate higher toxicity to the organisms. In accordance with testing regulation the limit test, preliminary tests and definitive test were conducted with single compounds. In limit test concentration $100 \mathrm{mg} \mathrm{L}^{-1}$ 
of tested compounds is used. Preliminary tests served to find approximate toxicity of the chemical compounds if is not known. In this case (range finding test) the dilution series was following $100 \mathrm{mg} \mathrm{L}^{-1}, 10 \mathrm{mg} \mathrm{L}^{-1}, 1 \mathrm{mg} \mathrm{L}^{-1}, 0,1 \mathrm{mg} \mathrm{L}^{-1}$ and 0,01. The definitive test served to calculation value of $\mathrm{LC}(\mathrm{EC}, \mathrm{IC}) 50$. Range of dilution series of the definitive test was determined by results of preliminary test.

From obtained experimental ecotoxicological endpoints (EC50, IC50, LC50) of ecotoxicity tests the quantification of ecotoxicity values is calculated. These parameters refer to the concentration of toxic substance that results in 50\% reduction of end-point relative to control at a given period of time (ISO/TS 20281:2006). The results of tests are suitable statistical evaluated with using the statistical software. The significant differences $(p<0.05)$ in the measured parameters in each of tests (inhibition of growth, immobilization etc.) are evaluated by ANOVA test.

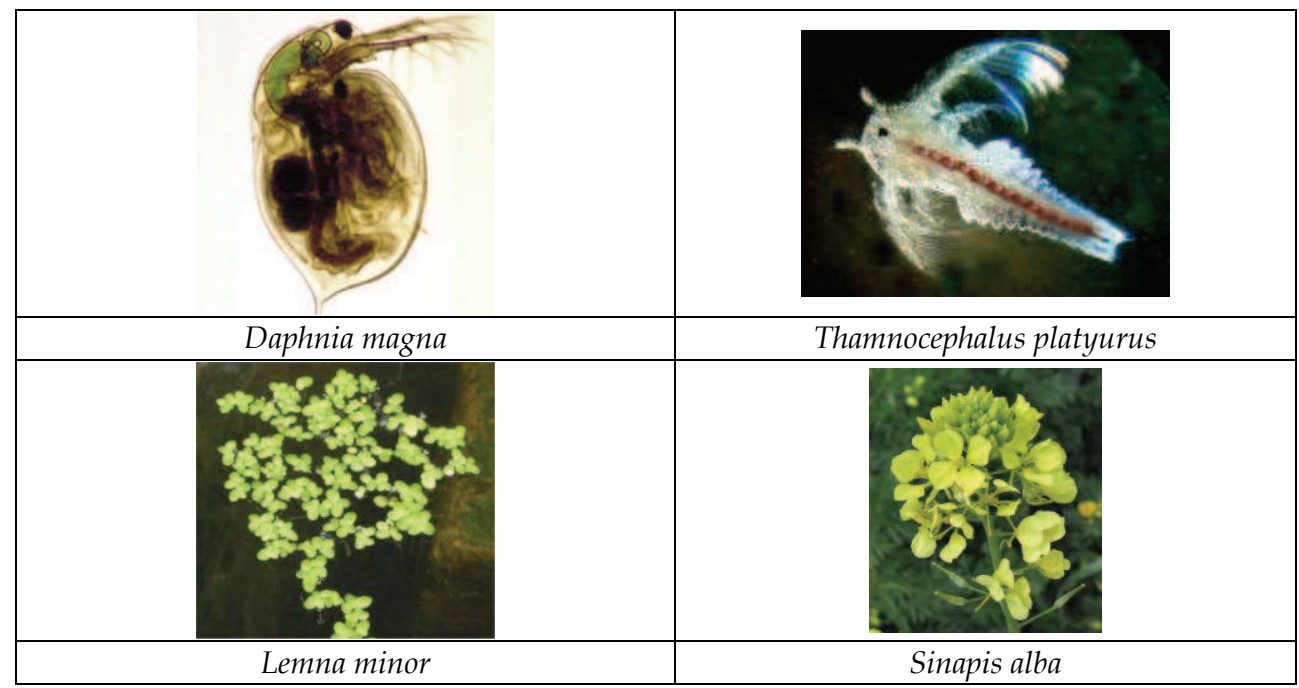

Fig. 5 The testing organisms

\subsubsection{Daphnia magna acute immobilization test}

The testing organisms Daphnia magna is a component of freshwater zooplankton. It refers to group Arthropoda, Branchiopoda, Daphnidae. Daphnia are small arthropods of 1-5 mm in size. They live in various aquatic environments ranging from acidic swamps to freshwater lakes, ponds, streams and rivers. Often they are found in large amounts. Ontogenesis of individual is direct without larval stages. During the year there is one or several biological cycles in which parthenogenetic generations are alternated by bisexual generations which enclose the cycle. This test serves for testing of effect of chemicals on plankton organisms. The importance of the test consists in plankton organisms served as feed for fish and are therefore significant component of water biocoenosis and food chain. For the calculation value of EC50 alternative Daphtoxkit FTM was used (purchased from MicroBioTests Inc., Gent, Belgium). This toxkit includes dormant eggs in chitinous capsule (ephippia) of crustaceans Daphnia magna. The Daphtoxkit FTM makes use of such dormant eggs produced under controlled conditions with a standard Daphnia magna strain. The tests were 
conducted following the Standard Operational Procedure of the Daphtoxkit FTM which is in accordance with the OECD and ISO test protocols for the acute Daphnia magna toxicity tests (OECD, 2004; ISO, 1996). Standard Freshwater was prepared with the concentrated salt solutions included in the kit. This medium, which has the composition recommended by the ISO for acute toxicity tests with Daphnia magna, is used as a hatching medium and as a dilution medium for the preparation of the toxicant dilution series. The assays were carried out in the multiwell test plates provided in the kits. Ephippia were hatched in petri disches with Standard Freshwater (ISO) medium three days before test at temperature $20-22{ }^{\circ} \mathrm{C}$, continuous illumination of 6000 lux. Two hours prior to test were the neonates pre-feeded wit suspension of spirulina powder to proved them energetic reserve. Daphnids aged less than 24 were exposed to dilution series of tested compounds. 20 individuals were subdivided in four replicates for every concentration of multiwell plate (well volume is 5 $\mathrm{ml}$ ). The some procedure was done with control Daphnids (20 individual subdivided in 4 wells). In fine was multiwell plate sealed with a strip of parafilm and covered with lid. Experiments were conducted at temperature $20^{\circ} \mathrm{C}$ in darkness incubator. Immobility (the endpoint for effect calculation) was obserwed after 24 and $48 \mathrm{~h}$. The values of $24 \mathrm{hEC} 50$ and $48 \mathrm{hEC} 50$ were calculated by probit analysis. The test was considered valid if the number of dead organisms in the control did not exceed $10 \%$.

\subsubsection{Thamnocephalus platyurus acute immobilization test}

For calculation value of LC50 alternative test Thamnotoxkit FTM was used (purchased from MicroBioTests Inc., Gent, Belgium). This test is often use to screening toxicity in freshwater and determination of acute toxicity Thamnotoxkit is similar to Daphtoxkit FTM contains all the materials to perform six complete acute (24-h) toxicity tests (range-finding or definitive) based on mortality as the effect criterion the assays were performed on larvae of the fairy shrimp Thamnocephalus platyurus hatched from cysts. The procedure of this test is similar as mentioned above. Standard freshwater was prepared by diluting the concentrated salt solutions included in the kit to obtain 11 of medium (moderately hard reconstituted freshwater made up according to the US EPA formula) which serve for hatching the cysts and to prepare the toxicant dilution series. The eggs of crustaceans were hatched 24 hours before testing at temperature $25^{\circ} \mathrm{C}$ under continuous illumination 4000 lux. Design of the test is similar to Daphtoxkit FTM test, multiwell plates are smaller ( $1 \mathrm{ml}$ volume), and number of testing organisms in each well is 10. Each toxicant concentration was tested out in three replicates. The test procedure followed the Standard Operational Procedure of the Thamnotoxkit FTM magna microbiotest. The test plates subsequently were incubated at 25 ${ }^{\circ} \mathrm{C}$ in darkness. Lethality (endpoint for effect calculation) was observed after $24 \mathrm{~h}$. The values of $24 \mathrm{hLC} 50$ were calculated by probit analysis. The test was considered valid if the number of dead organisms in the control did not exceed $10 \%$.

\subsubsection{Root growth inhibition toxicity test on Sinapis alba}

The test was developed for testing of harmlessness of waste waters, which could be used for sewage irrigation. Effect on seed germination and root growth of mustard (Sinapis alba) in first stadium of development is tested. Test consists of cultivation of the seeds on beds saturated with solutions of tested chemical in comparison with seeds grown on bed saturated with dilution medium. Mustard, Sinapis alba L., (Brassica alba L.) belongs to Brassicaceae. It is annual, early spring grown oil bearing plant. Mustard root is thin; shoot is erect, hairy and up to $150 \mathrm{~cm}$ high with clear green leaves. Seeds are relatively big, in 
comparison with other Brassicaceae and are yellow or whiteyellow of a round shape. They reach to $1.5-4 \mathrm{~mm}$ in diameter. After germination, simple root with hypocotyle grows up. The high quality seeds of Sinapis alba are exposed to solution of tested compounds at temperature $20 \pm 2{ }^{\circ} \mathrm{C}$ in the darkness incubator for 72 hours. The seeds (30 pieces) for every tested concentration are placed on filter paper in Petri-dishes. Paper is moistened with solution of tested compounds. Dilution series of tested compounds were prepared by dilution of stock solution of tested compounds in diluent medium. Diluent medium was prepared by filling up of $2.5 \mathrm{ml}$ from stock solution of every salt to 11 volume flask. Stock solution of $\mathrm{CaCl}_{2} \cdot 2 \mathrm{H}_{2} \mathrm{O}$ was prepared by solution of $11.76 \mathrm{~g} \mathrm{CaCl}_{2} \cdot 2 \mathrm{H}_{2} \mathrm{O}$ in 11 volume flask. The other stock solution was prepared by solution of $4,93 \mathrm{~g}$ of each salt $\left(\mathrm{MgSO}_{4} \cdot 7 \mathrm{H}_{2} \mathrm{O}, \mathrm{Na}\right.$ $\left.\mathrm{HCO}_{3}, \mathrm{KCl}\right)$ in 11 volume flask. Two replicates were done for every dilution series. For calculation values of IC50 the lengths of hypocotyls of germinated seeds in tested and in control group were measured. The inhibition of root growth (the endpoint for effect calculation) was measured after 72 hours. The test was considered valid if the number of germinated seeds in control was at least $90 \%$; organisms in the control did not exceed $10 \%$.

\subsubsection{Lemna growth inhibition test}

The test has been used for toxicity of solutions and suspensions testing. A higher freshwater plant, duckweed (Lemna minor L.) is used. From this point of view we can talk about semichronic exposition, where immediate effect, as well as long-term effect, is involved and visible in growth of new generation of plants.

Taxonomically Lemna minor L. belongs to angiosperms (Angiospermophyta) monocotyledonous plants (Monocotyledonopsida), Lemnaceae. These macrophytes take place at maintained water areas where they serve as feed e.g. for fish and water birds. Lemna minor (duckweed) cover surface of stagnant waters and are the most known species from pleustonic communities.

Lemna tests with duckweed Lemna minor were performed according OECD Test No. 221: Lemna sp. Growth Inhabition Test using Steinberg medium (OECD 2006). Biotest were carried out in $200 \mathrm{ml}$ beakers filled with $150 \mathrm{ml}$ solution (dilution series of tested compounds diluted in Steinberg medium). The beakers were inoculed with 14 fronds. Plants with two or three fronds were chosen as inoculum. Six control and treatment replicates were used. Test were carried out at temperature $24 \pm 2{ }^{\circ} \mathrm{C}$, light intensity was adjusted at 8000 lux. Test duration was 7 days $(168 \mathrm{~h})$. Number of fronds was controlled at days $0,3,5$ and 7 . The second monitored characteristic was the dry mass determinate at temperature $60{ }^{\circ} \mathrm{C}$ to constant weight. Dry mass was determined on the beginning of the test too. For this purposes were 6 additional control inoculated. Growth inhibition (measured as the increase in number of fronds during 7 days of incubation as compared to a corresponding control) was recorded after $168 \mathrm{~h}$. Growth inhibition as the toxicological endpoint served for calculation value of $168 \mathrm{hIC} 50$. The test was considered valid if the number of fronds grown eightfold.

\subsection{The ecotoxicity of chemicals}

Synthetic musk compounds, pharmaceutical residues (particularly analgesics and antibiotics) were ecotoxically evaluated. Ecotoxicity was assessed by alternative tests using species such as Thamnocephalus platyurus and Daphnia magma and a phytotest using white mustard (Sinapis alba) as a terrestrial testing organism and Lemna minor as water testing organisms. The mentioned species were used to assess the effect of musk compounds and 
pharmaceuticals on the aquatic ecosystem (Lemna minor, Thamnocephalus platyurus, Daphnia magna) and on terrestrial plants represented Sinapis alba. Test species mentioned above were also used to assess the ecotoxicity of sludge originating from a particular wastewater treatment plant, at some stages of sludge treatment.

\subsubsection{Ecotoxicological evaluation of pharmaceuticals}

Pharmaceuticals are environmentally were similar to other chemicals. In fact, high quantities of pharmaceuticals are discharged into sewage treatment plants. Local discharge of pharmaceuticals also contributes to environmental contamination due to high concentrations in small sites. The ecotoxicological effects of drugs on different levels of the biological hierarchy, from bacteria to the entire biosphere, are not well known. They are biologically active compounds that may interfere with specific biological systems (e.g. enzymes) or generically act depending on their properties. (Isidori et al. 2005). The growing use of direct toxicity assessment is a result of existing or new regulation implementing (e.g. EU Directive 93/67/EEC, REACH). International and national authorities have available ecotoxicity biotests which represent useful tools for the prediction of environmental impacts. EU Directive 93/67/EEC (Commission of the European Communities, 1996) classifies substances to their EC50 values in different classes; $<1 \mathrm{mg} \mathrm{L}^{-1}$, (very toxic to aquatic organisms); 1-10 $1 \mathrm{mg} \mathrm{L}^{-1}$ (toxic to aquatic organisms); $10-100 \mathrm{mg} \mathrm{L}^{-1}$ (harmful to aquatic organisms) substance with value EC50 above $100 \mathrm{mg} \mathrm{L}^{-1}$ would not be classified. Ibuprofen and diclofenac belong to the group of the nonsteroidal anti-inflamatory drugs. This one are the most frequently identified in detectable concentration in environment and in sewage water. The concentrations were between $0.01-510 \mu \mathrm{g} \mathrm{L}^{-1}$ for diclofenac and 0.49$990 \mu \mathrm{g} \mathrm{L}^{-1}$ for ibuprofen. Elimination of these pharmaceuticals in WWTP is something about $87 \%$ for ibuprofen and 49-59\% for diclofenac (Heberer, 2002; Kümmerer, 2002; Kosjek et al., 2007). Cleuvers (Cleuvers, 2003) summarized results of some studies. The following concentration are reported; diclofenac $\leq 1.59 \mu \mathrm{g} \mathrm{L}^{-1}$, ibuprofen $\leq 3.35 \mu \mathrm{g} \mathrm{L}-1$, acetylsalicylic acid (ASA) $1.51 \mu \mathrm{g} \mathrm{L}^{-1}$ in sewage, lower concentration (0.01-0.5 $\left.1 \mu \mathrm{g} \mathrm{L}^{-1}\right)$ in river water, Ternes (Ternes et al., 1998) reported concentration of above mentioned pharmaceuticals and of naproxen some $>1 \mu \mathrm{g} \mathrm{L}^{-1}$ in WWTP and again lower concentration in surface water. Data summarized by Watkinson (Watkinson, et al. 2007) indicate that WWTPs often partially remove selected drug $20-90 \%$. They could be present in effluents and consequently in surface water. Isidori (Isidori et al., 2005) reported results from studies concerning occurrence antibiotics in water; lincomycin, erythromycin and clarithromycin in the rivers Po and Lambro in Northern Italy were detected at concentrations between 10 and $100 \mathrm{ng} / \mathrm{L}$, in Switzerland, quinolones occurred at effluents at concentrations between 249 and $45 \mathrm{ng} / \mathrm{L}$, respectively. Reported concentration are not extremely high contrary others pollutans, but drugs should stay in the centre of researches, because of their biological activity.

Ecotoxicological evaluation of some pharmaceuticals were conducted: from the group of non-steroidal anti-inflammatory substances Diclofenac sodium (2-[(2,6dichlorophenyl)amino]benzeneacetic acid, Ibuprophen sodium 2-[4-(2methylpropyl)phenyl]propanoic acid, Ampicillin from the group of antibiotics. (2S,5R,6R)-6[[(2R)-2-amino-2-phenylacetyl]amino]-3,3-dimethyl-7-oxo-4-thia-1-azabicyclo[3.2.0]heptane2-carboxylic acid and Penicillin G 2S,5R,6R)-3,3-dimethyl-7-oxo-6-[(2-phenylacetyl)amino]4-thia-1-azabicyclo[3.2.0]heptane-2-carboxylic acid. Some studies were conducted to calculate ecotoxicological values for drugs. For diclofenac values of $30 \mathrm{minEC50}$ on Vibrio fischeri for were $11.45 \mathrm{mg} \mathrm{L}^{-1}$ for Cerodaphnia dubia value of $48 \mathrm{hEC50} 22.70 \mathrm{mg} \mathrm{L}^{-1}$ for Daphnia 
magna $68 \mathrm{mg} \mathrm{L}^{-1}$ and for Lemna minor EC50 $7.50 \mathrm{mg} \mathrm{L}^{-1}$. For ibuprofen value of EC50 101.20 $\mathrm{mg} \mathrm{L}^{-1}$ on Daphnia magna $342 \mathrm{mg} \mathrm{L}^{-1}$ in acute algal test on Desmodesmus subspicatus, $173 \mathrm{mg}$ $\mathrm{L}^{-1}$ in acute toxicity test on fish and $22.00 \mathrm{mg} \mathrm{L}^{-1}$ is value of EC50 for Lemna minor (Cleuvers, 2003; Ferrari et al., 2003; Ferrari et al., 2004; Jemba 2006).

Informations concerning ecotoxicity of penicillin $G$ and ampicillin on above mentioned organism are sporadic. Avaiable data served for preparing dilution series in preliminary tests. On the ground results of preliminary test were definitive test conducted. Achieved results summarized table 7 .

\begin{tabular}{|c|c|c|c|c|c|}
\hline \multirow{2}{*}{ Substances } & \multicolumn{2}{|c|}{ Daphnia magna } & \multirow{2}{*}{$\begin{array}{c}\text { Thamnocephalus } \\
\text { platyurus }\end{array}$} & \multirow{2}{*}{$\begin{array}{c}\text { Sinapis alba } \\
72 \mathrm{hIC50} \\
\text { (mg.L-1) }\end{array}$} & \multirow{2}{*}{$\begin{array}{c}\text { Lemna minor } \\
24 \mathrm{hLC} 50 \\
\left(\mathrm{mg} . \mathrm{L}^{-1}\right)\end{array}$} \\
\hline & $\begin{array}{c}24 \mathrm{hEC} 50 \\
\left(\mathrm{mg} \cdot \mathrm{L}^{-1}\right)\end{array}$ & $\begin{array}{c}\text { 48h EC50 } \\
\left(\mathrm{mg} \cdot \mathrm{L}^{-1}\right)\end{array}$ & & & \\
\hline Diclofenac-Na & $\begin{array}{c}53.0 \\
(48.6- \\
56,1) \\
\end{array}$ & $\begin{array}{c}17.2 \\
(15.8- \\
19.1) \\
\end{array}$ & $\begin{array}{c}169.4 \\
(162.2-174.1)\end{array}$ & $\begin{array}{c}83.8 \\
(77.6-85.4)\end{array}$ & $\begin{array}{c}15.2 \\
(13.6-16.2)\end{array}$ \\
\hline Ibuprophen-Na & $\begin{array}{l}106.4 \\
(96.4- \\
110.0) \\
\end{array}$ & $\begin{array}{c}56.4 \\
(53.7- \\
59.6) \\
\end{array}$ & $\begin{array}{c}195.9 \\
(188.7-197.0)\end{array}$ & $\begin{array}{c}122.2 \\
(118.6-125.4)\end{array}$ & $\begin{array}{c}200.8 \\
(196.4-205.0)\end{array}$ \\
\hline Penicillin-G & $\begin{array}{c}874.4 \\
(867.0- \\
879.5)\end{array}$ & $\begin{array}{c}878.5 \\
(871.8- \\
883.2)\end{array}$ & n.d. & $\begin{array}{c}653.4 \\
(647.1-655.6)\end{array}$ & $\begin{array}{c}857.2 \\
(854.3-860.3)\end{array}$ \\
\hline Ampicillin & $\begin{array}{c}823.2 \\
(815.0- \\
831.1)\end{array}$ & $\begin{array}{c}850.5 \\
(839.8- \\
858.4)\end{array}$ & n.d. & $\begin{array}{c}286.7 \\
(281.0-291.2)\end{array}$ & $\begin{array}{c}650.3 \\
(646.7-651.5)\end{array}$ \\
\hline
\end{tabular}

Table 7. The ecotoxicity endpoints to crustaceans and plant testing organisms for pharmaceuticals

In most of biotests diclofenac exhibits greatest ecotoxicity, follows ibuprofen, ampicillin and penicillin G. It corresponds with results presented by Wollenberg (Wollenberg et al., 2000). Ecotoxicological values for some antibiotics were approximately $1000 \mathrm{mg} . \mathrm{L}^{-1}$ oxytetracycline, $680 \mathrm{mg} . \mathrm{L}^{-1}$ tylosine. It seems that antibiotics of penicillane (penicillin, ampicilin ) and tetracycline (oxytetracycline) exhibit only low acute toxicity. According EU Directive $93 / 67 /$ EEC belongs to the group of chemicals which would not be classified. Ibuprofen and diclofenac on the basic of scheme of classification would be classified as potentially harmful to aquatic organisms. In spite of higher ecotoxicity of NSAIDs acute toxicity is unlikely. With regard to purpose for which pharmaceuticals are generated (bring some benefit to alive organisms) strong acute effects caused by specific mechanisms may actually not be expected. In addition value of EC50 for Daphnia magna is manifold higher than measured in environment. From this point of view is prediction of chronic effect much more relevant. Moreover residues of pharmaceuticals do not exist by itself in the environment. Toxicity of a single substance could increase strongly in combination with other especially when mode of action is similar. On the basis of these facts is necessary to test toxicity of mixture compounds on battery of organisms representing various levels of ecosystem (Cleuvers 2003 \& Fatta-Kassinos, 2010). 


\subsubsection{Ecotoxicological evaluation of musk compounds}

Polycyclic musks, the common name for synthetic musks with rings in their chemical structure, are the most commonly produced and used musks. They include substances such as traseolide (ATII), celestolide (ADBI), fixolide/tonalide (AHTN), versalide (ATTN), galaxolide (HHCB), etc. Nitromusks, the common name for a group of (artificial) nitrogencontaining musks (produced by nitration of organic compounds), includes a number of compounds, such as: musk ketone, musk ambrette, musk tibetene, musk alpha and musk moskene (in addition to musk xylene) (; Balk and Ford, 1999; HERA, 2004).

The musk tested compounds were Galaxolide, 1,3,4,6,7,8-hexahydro-4,6,6,7,8,8-hexamethylcyclopenta[g]-2-benzopyrane, Tonalide 1-(5,6,7,8-tetryhydro-3,5,5,6,8,8-hexamethyl-2naphthalenyl)-ethynone, Musk-ketone 1-tert-butyl-3,5-dimethyl-2,6-dinitro-4-acetylbenzene and Musk-xylene 1-tert-butyl-3,5-dimethyl-2,4,6-trinitrobenzene.

The effect of musk compounds on the organism were studied from several view namely for one organism as the acute or subchronic toxicity (Boleas et al. 1996; Carlsson \& Norrgren 2003; Dietrich \& Hitzfeld 2004; Mori et al. 2006). The acute toxicity of AHTN and HHCB were tested on the algae (Pseudokirchineriella subscapitata), crustacean (Daphnia magna), springtails (Folsomia candida), nematode worm (Caenorhabditis elegans), earthworms (Eisenia fetida), rainbow trout (Oncorhynchus mykiss), zebrafish (Danio rerio), brook minnow (Pimephales promelas), South African frog (Xenopus laevis) and bluegill sunfish (Lepomis macrochirus).

The table 8. shows the ecotoxicological obtained dates from using tests for tonalide, galaxolide, musk ketone and musk xylene.

\begin{tabular}{|c|c|c|c|c|c|}
\hline \multirow{2}{*}{ Substances } & \multicolumn{2}{|c|}{ Daphnia magna } & \multirow{2}{*}{$\begin{array}{c}\text { Thamnocephalus } \\
\text { platyurus }\end{array}$} & \multirow{2}{*}{$\begin{array}{c}\text { Sinapis alba } \\
72 \mathrm{hIC50} \\
\left(\mathrm{mg} \cdot \mathrm{L}^{-1}\right)\end{array}$} & \multirow{2}{*}{$\begin{array}{c}\text { Lemna minor } \\
24 \mathrm{hLC50} \\
\left(\mathrm{mg} \cdot \mathrm{L}^{-1}\right)\end{array}$} \\
\hline & $\begin{array}{c}\text { 24hEC50 } \\
\left(\mathrm{mg} . \mathrm{L}^{-1}\right)\end{array}$ & $\begin{array}{c}\text { 48h EC50 } \\
\left(\mathrm{mg} . \mathrm{L}^{-1}\right)\end{array}$ & & & \\
\hline $\begin{array}{l}\text { Tonalide } \\
\text { (AHTN) }\end{array}$ & $\begin{array}{c}1.51 \\
(1.48- \\
1.53)\end{array}$ & $\begin{array}{c}1.33 \\
(1.29- \\
1.36)\end{array}$ & $\begin{array}{c}1.58 \\
(1.55-1.60)\end{array}$ & $\begin{array}{c}5.42 \\
(5.38-5.45)\end{array}$ & $\begin{array}{c}5.20 \\
(5.18-5.22)\end{array}$ \\
\hline $\begin{array}{c}\text { Galaxolide } \\
\text { (HHCB) }\end{array}$ & $\begin{array}{c}1.22 \\
(1.19- \\
1.24)\end{array}$ & $\begin{array}{c}1.12 \\
(1.08- \\
1.13)\end{array}$ & $\begin{array}{c}1.14 \\
(1.11-1.16)\end{array}$ & $\begin{array}{c}4.92 \\
(4.87-4.95)\end{array}$ & $\begin{array}{c}4.62 \\
(4.58-4.66)\end{array}$ \\
\hline Musk ketone & $\begin{array}{c}2.33 \\
(2.28- \\
2.35)\end{array}$ & $\begin{array}{c}2.13 \\
(2.10- \\
2.15)\end{array}$ & $\begin{array}{c}6.14 \\
(6.12-6.17)\end{array}$ & $\begin{array}{c}4.84 \\
(4.79-4.87)\end{array}$ & $\begin{array}{c}5.36 \\
(5.32-5.40)\end{array}$ \\
\hline Musk xylene & $\begin{array}{c}2.39 \\
(2.32- \\
2.41)\end{array}$ & $\begin{array}{c}2.22 \\
(2.18- \\
2.26)\end{array}$ & $\begin{array}{c}6.16 \\
(6.13-6.20)\end{array}$ & $\begin{array}{c}5.68 \\
(5.65-5.71)\end{array}$ & $\begin{array}{c}5.36 \\
(5.33-5.39)\end{array}$ \\
\hline
\end{tabular}

Table 8 . The ecotoxicity endpoints to crustaceans and plant testing organisms for polycyclic musks and nitomusks

The higher ecotoxicity is typical for polycyclic musk compounds (AHTN and HHCB), but results showed the lower ecotoxicity for nitromusk compounds (musk ketone and musk xylene). The sensitivity of organisms is various. The fresh crustaceans (Daphnia magna and Thamnocephalus platyurus) and Lemna minor are most sensitive than terrestrial plant (Sinapis alba). 


\subsection{Ecotoxicological evaluation of the sludges from wastewater treatment plant (WWTP)}

Modern sanitary practices result in large volume of human waste, as well as domestic and industrial sewage, which are collected and treated at common collection points WWTP. The growing use of sewage sludge as fertilizer results in many studies concerning their chemical analysis and hazard assessment (Jones-Lepp and Stevens, 2003; Fatta-Kassinos et al., 2010). Wastewater undergo preliminary, primary, secondary and in same cases tertiary treatment before sewage sludge are produced. Wastewater treatment unit operations and processes have three important parts. Physical unit operations - screening, comminution, flow equalization, sedimentation, flotation, granular-medium filtration, Chemical unit operations - chemical precipitation, adsorption, disinfection, dechlorination, other chemical applications, Biological unit operations - activated sludge process, aerated lagoon, trickling filters, rotating biological contactors, pond stabilization, anaerobic digestion, biological nutrient removal. Sludge resulting from wastewater treatment operations is treated by various methods in order to reduce its water and organic content and make it suitable for final disposal and reuse. Anaerobic wastewater treatment is the biological treatment of wastewater without the use of air or elemental oxygen. Anaerobic digestion/stabilization reduces the volatile solid content by approx. 60 to $65 \%$, and significantly reduces pathogens. The sludges from waste water treatment are several types and its composition and properties depend on the level of the waste treatment.

- Raw sludge is untreated non-stabilized sludge. It tends to acidify digestion and produces odours.

- Primary sludge is produced through the mechanical wastewater treatment process. The sludge amassing at the bottom of the primary sedimentation basin is also called primary sludge. Primary sludge consists to a high portion of organic matters, as faeces, vegetables, fruits, textiles, paper etc.

- Activated Sludge - The removal of dissolved organic matter and nutrients from the wastewater takes place in the biological treatment step. It is done by the interaction of different types of bacteria and microorganisms. The resulting sludge from this process is called activated sludge. The activated sludge exists normally in the form of flakes, which besides living and dead biomass contain adsorbed, stored, as well as organic and mineral parts.

- Return activated sludge - The activated sludge flows from the biological aeration basin into the final clarifier. The main part of the separated sludge, which is transported back to the aeration basin, is called return activated sludge.

- $\quad$ Secondary sludge (Excess sludge) - To reach a constant sludge age the unused biomass has to be removed from the biological treatment system as excess sludge. The excess sludge contains not-hydrolysable particulate materials and biomass due to metabolisms.

- $\quad$ Tertiary sludge - Tertiary sludge is produced through further wastewater treatment steps e.g. by adding a flocculation agent.

The sludges from WWTP are various applications, mainly in agricultures and recultivation in relation to environmental Directive 86/278/EEC (Council directive, 1986). On the other hand they could represent big problem because of concentrated xenobiotics. The heavy metals $\mathrm{Zn}, \mathrm{Cu}, \mathrm{Co}, \mathrm{Pb}, \mathrm{Hg}, \mathrm{Cr}$, Cd, anthropogenic xenobiotics (PCB, dioxins, $\mathrm{PAHs}$, etc) are serious contaminants of sludges. The stabilized sludges with containing organic matter, 
nutrients and biologically active substances represent the source of failure nutrients and elements $(\mathrm{N}, \mathrm{P}, \mathrm{K}, \mathrm{Ca}, \mathrm{Mg})$ and also organic matter, but their application on the land is limited by xenobiotics and pathogen organisms. In 2006, were produced in Czech republic 220700 tons of sewage sludge (expressed in dry matter) $75 \%$ of sewage sludge was landapplied, 0,9 \% incinerated, 13 used in other methods and $13 \%$ were disposed on dumps. Ratio of disposed sewage is relatively high. Some studies indicate that not only traditional analytes [i.e., PAHs, PCBs, polychlorinated naphthalenes (PCNs -structurally similar to PCBs, several of which exhibit dioxin- like toxicity), polychlorinated n-alkanes (PCAs)], and for a class of PPCPs - synthetic musks are present at significant concentrations (Jones-Lepp and Stevens, 2003). The Hazardous Waste Council Directive 91/689/EEC set the rules for the management, recovery and correct disposal of hazardous wastes. The directive has established, in its Annex I, different categories of wastes In order to characterise wastes as hazardous, must display any of the 14 properties specified in Anne III. Property labelled H14 - "ecotoxic" exhibits substances and matrices which present or may present immediate or delayed risk for one or more sectors of the environment (Pablos et al., 2009). To decide if wastes are hazardous ecotoxicological values LC(EC, IC) 50 resulting from bioassay provided by legislation on Daphnia magna, Sinapis alba, fresch water algal Scenedesmus subspicatus and vertebrate Danio rerio are required.

Sludge mainly collected from wastewater treatment plants (WWTP Brno-Modřice) were subjected to ecotoxicological characterization to provide a preliminary assessment of their ecotoxicity. The various type of sludges were analyzed - anaerobic stabilized sewage sludge (AS), dewatered anaerobic stabilized sewage sludges (DWAS) and desiccated stabilized sewage sludge (DSAS) and activated sludge (ASV) from the small WWTP of the University of Veterinary and Pharmaceutical Sciences in Brno were tested. Several toxicity tests were performed under standard laboratory conditions using freshwater crustaceans (Daphnia magna, Thamnocephalus playturus) and aquatic and terrestrial plants Sinapis alba. The values of $24 \mathrm{hLC} 50,48 \mathrm{hEC} 50$ and $72 \mathrm{hIC50}$ are the basic data for the ecotoxicological assessment of the sludge and for their classification following the Czech legislation. Following legislation concerning ecotoxicological evaluation of waste were the test conducted on water leaches of sewage. Wastes are extracted with the corresponding test medium in ratio $10 \mathrm{~L} / \mathrm{kg}$ dry water for $24 \mathrm{~h}$. Leaches were diluted using dilution medium corresponding to each testing organism in dilution series similarly to procedure with chemical substances $(50,100,300$, $500,700 \mathrm{ml} \mathrm{L}^{-1}$ and leach non-diluted only saturated with salt belonging to testing organisms - I series). To compare ecotoxicity of sewage of various humidity, were sludge diluted with water to have uniform dry matter as the most humid sewage (AS - II series. In case that

\begin{tabular}{ccccccc}
\hline & \multicolumn{2}{c}{ Daphnia $48 \mathrm{hEC50}\left(\mathrm{ml} \mathrm{L}^{-1}\right)$} & \multicolumn{2}{c}{ Thamnocephalus $24 \mathrm{hLC50}\left(\mathrm{ml} \mathrm{L}^{-1}\right)$} & \multicolumn{2}{c}{ Sinapis 72hIC50 $\left(\mathrm{ml} \mathrm{L}^{-1}\right)$} \\
& I series & II series & I series & II series & I series & II series \\
\hline AS & 52.04 & - & 22.81 & - & 203.62 & - \\
DWAS & 136.38 & 340.37 & 39.57 & 128.02 & 262.00 & - \\
DSAS & 236.42 & 540.21 & 139.64 & 343.15 & 266.56 & - \\
ASV & 38.17 & 426.89 & 129.57 & 422.34 & - & - \\
\hline
\end{tabular}

- value of IC50 could not be calculated because of growth inhibition was below $50 \%$

Table 9. The values of LC(EC, IC) 50 calculated for various type of sewage sludge 
values of LC(EC, IC)50 resulting from bioassays provided by Czech legislation are higher or equal to $10 \mathrm{ml} \mathrm{L}^{-1}$ at least for one of testing organisms (Daphnia magna, Sinapis alba, fresch water algal Scenedesmus subspicatus and vertebrate Danio rerio) are the waste evaluated as hazardous. Calculated values of LC(EC, IC)50 are in table 9.

In spite of the fact that testing organisms are not the same as define Czech legislation we can predict that in no case sewage exhibit property labelled H14. Obtained values are above 10 $\mathrm{ml} \mathrm{L}^{-1}$ in all case. The most sensitive organisms are crustacean especially Thamnocephalus platyurus. As environmentally friendly appears DWAS and DSAS - activated sludge which is anaerobic stabilized and dewatered and consequently desiccated. It is possible that these processes decrease amount of some water soluble or temperature instable xenobiotics. The ecotoxicity assays confirmed that no sludge constituted a hazardous waste from ecotoxicological point of view. Our results are in according to recent study concerning ecotoxicity assays of different sludge (aerobic, anaerobic, unstabilised and sludge from a waste stabilisation pond) which confirmed that no sludge constituted a hazardous waste (Fuentes et al., 2006). The other question is if the bioassays of water leaches are relevant to predict ecotoxicity of solid matrices (waste, sediments, sewage). The aim of study conducted on various organisms by (Leitgib et al. 2007; Domene et al., 2008) was to assess applicability and reliability of several environmental toxicity tests, comparing the result of the whole soils and their water extracts. Measured endpoints were the bioluminescence inhibition of Vibrio fischeri (bacterium), the dehydrogenase activity inhibition of Azomonas agilis (bacterium), the reproduction inhibition of Tetrahymena pyriformis (protozoon), and Panagrellus redivivus (nematode), the mortality of Folsomia candida (springtail), the root and shoot elongation inhibition of Sinapis alba (plant: white mustard) and the nitrification activity inhibition of an uncontaminated garden soil used as "test organism". In most cases, the contact ecotoxicity tests conducted on solid matrices indicated more harmful effect of these samples than the tests using matrices extracts.

\begin{tabular}{|c|c|c|c|c|c|}
\hline Organisms & Type of test & Endpoinds & $\begin{array}{l}\text { Exposition } \\
\text { time }\end{array}$ & Result & Directiva \\
\hline \multicolumn{6}{|c|}{$\begin{array}{l}\text { Tests of solid } \\
\text { waste }\end{array}$} \\
\hline $\begin{array}{c}\text { Eisenia fetida - } \\
\text { springtail }\end{array}$ & acute & mortality & 14 days & LC50 & $\begin{array}{c}\text { ISO } \\
11268-1\end{array}$ \\
\hline $\begin{array}{c}\text { Avena saitva, Brasicca } \\
\text { rapa - plants }\end{array}$ & acute & $\begin{array}{l}\text { germination, } \\
\text { growth inhibition }\end{array}$ & 14 days & IC50 & $\begin{array}{c}\text { ISO } \\
11269-2\end{array}$ \\
\hline \multicolumn{6}{|c|}{$\begin{array}{c}\text { Test of water leach } \\
\text { of waste }\end{array}$} \\
\hline $\begin{array}{l}\text { Vibrio fischeri - } \\
\text { bacterium }\end{array}$ & acute & $\begin{array}{l}\text { inhibition of } \\
\text { luminescence }\end{array}$ & $30 \mathrm{~min}$ & EC50 & ISO 11348 \\
\hline $\begin{array}{l}\text { Daphnia magna - } \\
\text { crustacean }\end{array}$ & $\begin{array}{l}\text { acute/chro } \\
\text { nic }\end{array}$ & $\begin{array}{l}\text { inhibition of } \\
\text { mortality }\end{array}$ & $48 \mathrm{~h}$ & EC50 & ISO 6341 \\
\hline $\begin{array}{c}\text { Desmodesmus } \\
\text { subspicatus, } \\
\text { Pseudokirchneriella } \\
\text { subcapitata - algae }\end{array}$ & chronic & growth inhibition & 3 days & EC20 & ISO 8692 \\
\hline
\end{tabular}

Table 10. Fundamental battery of ecotoxicity test for ecotoxicological evalution of solid matrices 
Direct contact environmental toxicity tests are more reliable and enable better prediction of environmental risk of tested matrices. Based on several studies (Rojičková et al., 1998; Leitgig et al., 2007; Pablos et al., 2009) resulting in similar findings are in Czech recommended another test inclusive obligatory battery of tests mentioned in Czech Legislation. The direct contact environmental toxicity bioassays are able to follows the requirements of environmental toxicology: reliability, sensibility, reproducibility, rapidity and low cost.

\section{References}

Alcock, R.E.; Bacon, J.; Bardget, R. D.; Beck, A. J.; Haygarth, P. M.; Lee, R. G. M.; Parker, C. A. \& Jones K. C. (1996). Persistence and fate of polychlorinated biphenyls (PCBs) in sewage sludge-amended agricultural soils, Environmental Pollution, Volume 93, 8392.

Balk, F.\& Ford, R.A. (1999). Environmental risk assessment for the polycyclic musk AHTN and HHCB in EU, I. Fate and exposure assessment, Toxicol Let 111, 57-79.

Beausse, J. (2004). Selected drugs in solid matrices: a review of environmental determination, occurrence and properties of principal substances, Trends in Analytical Chemistry 23, 753-761.

Bester, K. (2009). Analysis of musk fragrances in environmental samples, J Chromatogr A $1216,470-480$.

Blaise, Ch. (1991). Microbiotests in aquatic ecotoxicology: Characteristics, utility, and prospects, Environmental Toxikology and Water. Quality 6, 145-155.

Boleas, S.; Fernandez, C. \& Tarazona, J.V. (1996). Toxicological and kinetic study of musk xylene in rainbow trout, Oncorhynchus mykiss, Bull Environ Contam Toxicol 57, 217222.

Carlsson, G. \& Norrgren, L. (2004). Synthetic Musk Toxicity to Early Life Stages of Zebrafish (Danio rerio), Arch. Environ. Contam. Toxicol 46, 102-105.

Cleuvers, M. (2003). Aquatic ecotoxicity of pharmaceuticals incuding the assessment of combination effects, Toxikology letters 142, 185-194.

Cleuvers, M. (2003). Mixture toxicity of the anti-inflammatory drugs diclofenac, ibuprofen, naproxen, and acetylsalicylic acid, Ecotoxicology and Environmentla safety 59, 2004, 309-315.

Cleuvers, M. (2004). Mixture toxicity of the anti-inflamatory druha diclofenac, ibuprophen, naprošen and acetylsalicylic acid, Ecotoxicology and Environmental Safety 59, 309-315.

Commission of the European Communities, 1996. Technical Guidance Document in Support of Commission Directive 93/67/EEC on Risk Assesssment for New Notified Substances and Commission Regulation (EC) No. 1488/94 on Risk Assessment for Existing Substances. Part II: Environmental Risk Assessment. Office for Official Publications of the European Communities, Luxembourg.

Council of th European Communities (1986) council directive 86/278/EEC of 12 June 1986 on the protection of the environmnet, and particular of the soil, when sewage sludges is used in agriculture, official Journal L, 181:0006-0012

Dietrich. D.R. \& Hitzfeld, B.C. (2004). Bioaccumulation and Ecotoxicity of Synthetic Musks in the Aquatic Environment. Chapter in: Gerhard G Rimkus (ed) Synthetic Musk Fragrances in the Environment, Springer-Verlag, Berlin 233-244. 
Domene, X.; Alcañiz J.M. \& Andrés, P. (2008). Comparison of solid-phase and eluate assays to gauge the ecotoxicological risk of organic wastes on soil organisms, Environ Pollut. 151, 549-58.

EC, 1991. Council Directive 91/689/EEC of 12 December 1991 on hazardous waste. Off. J. Eur. Commun. L Legis 1991;377:0020-7 [31/12/1991].

Eljarrat, E.; Caixach, J. \& Riva J.(2001). Evaluation of dioxin contamination in sewage sludge discharges on coastal sediments from Catalonia, Spain, Water Research 35, 2799-280.

Fatta, D.; Nikolaou, A.; Achilleos, A. \& Meric, S. (2007). Analytical methods for tracing pharmaceutical residues in water and wastewater, Trends in Analytical Chemistry 26, 515-533.

Fatta-Kassinos, D.; Kalavrouziotis, I.K.; Koukoulakis, P.H. \& Vasquez, M.I. (2010). The risk associated with wastewater reuse and xenobiotics in the agrioecological environment, Science of The Total Environment, In Press, Corrected Proof.

Ferrari, B.; Paxéus, N.; Lo Giudice, R.; Pollio, A. \& Garric, J. (2003). Ecotoxicological impact of pharmaceuticals found in treated wastewaters: study of carbamazepine, clofibric acid, and diclofenac, Ecotoxicol Environ Saf 55, 359-370.

Ferrari, R.; Mons, B.; Vollat, B.; Frayse, B.; Paxéus, N.; Lo Guidice, R.; Pollio, A. \& Garric, J. (2004). Environmental risk assessment of six human pharmaceuticals: are the current environmental risk assessment procedures sufficient for the protection of the aquatic environment?, Environ Toxicol Chem 23, 1344-1354.

Fromme, H. Otto, T. \& Pilz, K. (2001). Polycyclic musk fragrances in different environmental compartments in Berlin (Germany), Water Res 35,121-128.

Fuentes, A.; Lloréns, M.; Sáez, J.; Aguilar, M.I.; Pérez-Marín, A.B.; Ortuo, J.F. \& Meseguer V.F. (2004). Ecotoxicity, phytotoxicity and extractability of heavy metals from different stabilised sewage sludges, Environmental Pollution 143, 355-360.

Gómez, J. M.; Petrovic, M.; Fernandez-Alba, A. R.; \& Barcelo, D. (2006). Determination of pharmaceuticals of various therapeutic classes by solid-phase extraction and liquid chromatography-tandem mass spectrometry analysis in hospital effluent wastewaters, Journal of Chromatography A. 1114, 224-233.

Halling-Sörensen, B.; Nors Nielsen, S., Lanzky, P.F.; Ingerslev, F.; Holten Lützhoft., H.C. \& Jörgensen, S.E. (1998). Occurrence, Fate and Effects of Pharmaceutical Substances in the Environment - A Review, Chemosphere 36, 357-393.

Heberer, H. (2002). Tracking persistent pharmaceutical residuem from municipal sewage to drinking water, Journal of Hydrology 266, 175-189.

Heberer, T.(2002). Occurrence, fate, and removal of pharmaceutical residues in the aquatic environment: A review of recent research data, Toxicology Letters 131, 5-17.

HERA (2004). Polycyclic Musks AHTN (CAS 1506-02-1) and HHCB(CAS 1222-05-05): Human and Environmental Risk Assessment on Ingredients of Household Cleaning Products; Environmental Section, Version 2:1-81

Herren, D.; Berset, J. D. (2000). Nitro musks nitro musk amino metabolites and polycyclic musks in sewage sludges. Quantitative determination by HRGC-ion-trap-MS/MS and mass spectral characterization of the aminometabolites, Chemosphere 40, 565574 .

Hirsch, R.; Ternes, T.A.; Haberer, K.; \& Kratz, K.L. (1999). Occurrence of antibiotics in the aquatic environment, Sci. Total Environ. 225, 109-118. 
Hoffman, D.J.; Rattner, B.; Burton, G.A.; \& Cairns, J. Handbook of Ecotoxicology. 2nd edition, Lewis Publisher 2003, 1290p. ISBN 1-56670-546-0.

Isidori, M.; Lavorgna, M.; Nardelli, A.; Pascarella, L. ; \& Parrella, A. (2005). Toxic and genotoxic evaluation of six antibiotics on non-target organisms, Science of The Total Environment 346, 87-98.

ISO 11268-1:1993 : Effects of pollutants on earthworms (Eisenia fetida) -- Part 1: Determination of acute toxicity using artificial soil substrate

ISO 11268-2:1998 : Soil quality -- Effects of pollutants on earthworms (Eisenia fetida) -- Part 2: Determination of effects on reproduction

ISO 11348-3:2007 Water quality -- Determination of the inhibitory effect of water samples on the light emission of Vibrio fischeri (Luminescent bacteria test) -- Part 3: Method using freeze-dried bacteria

ISO 20079:2005 Water quality - Determination of the toxic effect of water constituents and waste water on duckweed (Lemna minor) - Duckweed growth inhibition test

ISO 6341:1996 Water quality - Determination of the inhibition of the mobility of Daphnia magna Straus (Cladocera, Crustacea) - Acute toxicity test

ISO 8692:2004 Water quality -- Freshwater algal growth inhibition test with unicellular green algae

ISO/TS 20281:2006 Water quality - Guidance on statistical interpretation of ecotoxicity data

Jjemba, P.K. (2006). Excretion and ecotoxicity of pharmaceutical and personal care products in the environment, Ecotoxicol Environ Saf 63, 113-30.

Jones-Lepp, \& T.L.; Stevens, R. (2006). Pharmaceuticals and personal care products in biosolids/sewage sludge: the interface between analytical chemistry and regulation, Analytical and Bioanalytical Chemistry 38, 1173-1183.

Kasprzyk-Hordern, B.; Dinsdale, R.M. \& Guwy, A.J.(2008). The occurrence of Pharmaceuticals, personal care products endocrine disruptors and illicit drugs in surface water in South Wales, UK, Water Research 42, 3498-351.

Kay, P.; Blackwell, P.A.; Boxall \& A.B.A. (2005). Transport of veterinary antibiotics in overland flow following the application of slurry to arable land, Chemosphere 59, 951-959.

Koschorreck, J.; Koch, C. \& Ronnefahrt, I. (2002). Environmental risk assissment of veterinary medicinal products in the EU - a regulatory perspective, Toxicology Letters 131, 117-124.

Kosjek, T.; Heath, E. \& Kompare, B. (2007). Removal of pharmaceutical residues in a pilot wastewater treatment plant. Analytical and bioanalytical chemistry. 2007, vol. 387, no. 4, pp. 1378-1387

Kot-Wasik, A.; Debska, J. \& Namieśnik, J. (2007). Analytical techniques in studies of the environmental fate of pharmaceuticals and presonal-care products, Trends in Analytical Chemistry 26, 557-568.

Kümmerer, K. (2002). Drugs in the environment: Emission of drugs, diagnostic aids and disinfectants into wastewater by hospitals in relation to other sources-a review, Chemosphere 45, 957-969.

Lapen, D.R,; Topp, E,; Metcalfe, CD.; Li, H.; Edwards, M.; Gottschall, N.;, Bolton,P.; Curnoe, W.; Payne, M. \& Beck, A. (2008). Pharmaceutical and personal care products in tile drainage following land application of municipal biosolids, Sci Total Environ. 25; 50 65. 
Lee, I.S.; Lee, S.H.; Oh, J.E. (2010). Occurrence and fate of synthetic musk compounds in water environment, Water Res 44, 214-222.

Leitgib, L.; Kálmán, J. \& Gruiz, K. (2007). Comparison of bioassays by testing whole soil and their water extract from contaminated sites. Chemosphere 66, 428-434.

Lignell, S.; Darnerud, P.O.; Aune, M.; Cnattingius, S.; Hajslova, J.; Setkova, L. \& Glynn, A. (2008). Temporal trends of synthetic musk compounds in mother's milk and associations with personal use of perfumed products, Environ Sci Technol 42, 67436748.

Luckenbach, T.\& Epel, D. (2005). Nitromusk and polycyclic musk compounds as long-term inhibitors of cellular xenobiotic defense systems mediated by multidrug transporters, Environ Health Perspect 113, 17-24.

McClellan, K. \& Halde, R.U. (2010). Pharmaceuticals and personal care products in archived U.S. biosolids from the 2001 EPA national sewage sludge survey, Water Research 44, Pages 658-668.

Mendonca, E.; Picado, A.; Paix?o S.M.; Silva, L.; Cunha, M.A. Leit?o, S.; Moura, I.; Cortez, C. \& Brito, F. (2009). Ecotoxicity tests in the environmental analysis of wastewater treatment plants: Case study in Portugal, Journal of Hazardous Materials 163,665-670.

Mori. T.; Morita, F.; Inokuchi, A.; Takao, Y.; Kohra, S.; Tominaga, N.; Takemasa, T. \& Arizono, K. (2006). Ecotoxicological Effect of Polycyclic Musks on Caenorhabditis elegans, J Health Sci 52,276-282.

Nakata, H.; Sasaki, H.; Takemura, A.; Yoshioka, M, Tanabe, S. \& Kajman, K. (2007). Bioaccumulation, Temporal Trend, and Geographical Distribution of Synthetic Musks in the Marine Environment, Environ Sci Technol 41, 2216-2222.

OECD (2004): Guideline for the Testing of Chemicals. Daphnia sp. Acute immobilization Test No. 202. OECD, Paris, France

OECD (2006): Guideline for the Testing of Chemicals. Lemna sp. Growth inhibition test No. 221. OECD, Paris, France

Onesios, K.M.; Yu, J.T. \& Bouwer, E.J. (2009). Biodegradation and removal of pharmaceuticals and personal care products in treatment systems: a review, Biodegradation 20, 441-466.

Pablos, M.V.; Fernández, C.; del Mar Babín, M.; Navas, J. M.; Carbonell, G.; Martini, F.; García-Hortugüela, P. \& Tarazona J.V. (2009). Use of a novel battery of bioassays for the biological characterisation of hazardous wastes, Ecotoxicology and Environmental safety 72, 1594-1600.

Park, S. G.; Chung, Ch. S.; Lee, S. H.; Hong, G.; Kim, S. H; Park, S. Y; Yoon, S. Y. \& Lee, S. M. (2005). Ecotoxicological Evaluation of Sewage Sludge Using Bioluminescent marine Bacteria and Rotifer, Ocean Science Journal 40, 91-100.

Peck, A.M. (2006) Analyticla methods for the detetrmination of persitent ingredients of personál care products in environmnetla matricesa, Anal. Bioanal. Chem. 386, 907939.

Ramirez, A., J.; Mottaleb, M., A.; Brooks, B., W. \& Chambliss, K., C. (2007). Analysis of Pharmaceuticals in Fish Using Liquid Chromatography-Tandem Mass Spectrometry, Analytical Chemistry 79, 3155-3163.

Registration, Evaluation, Authorization and Restriction of C (REACH), regulation (EC) No 1907/2006 of the European Parliament and of the Council, 2006. 
Regueiro, J.; Garcia-Jares, C.; Llompart, M. Lamas, J.P. \& Cela, R. (2009). Development of a method based on sorbent trapping followed by solid-phase microextraction for the determination of synthetic musks in indoor air, J Chromatogr A 1216, 2805-2815.

Roberts, P.H. \& Thomas, K.V. (2006) The occurrence of selected Pharmaceutical in wastewater effluent and surface waters of the lower Tyne catchment, Science of the Total Environment $356,143-153$.

Rojíčková-Padrtová, R.; Maršálek, B. \& Holoubek, I. (1998). Evaluation of alternative and standard toxicity assays for screening of environmental samples: Selection of an optimal test battery, Chemosphere 37, 495-507.

Schowanek, D.; Carr, R.; David, H.; Douben, P.; Hall, J.; Kirchmann, H.; Patria, L.; Sequi, P.; Smith, S. \& Webb, S. (2004). A risk-based methodology for deriving quality standards for organic contaminants in sewage sludge for use in agricultureconceptual framework, Regul. Toxicol. Pharm. 40, 227-251.

Stevens, J.L.; Stern, G.A. Tomy, G.T. \& Jones, K.C. (2003). PAHs, PCBs, PCNs, organochlorine pesticides, synthetic musks and polychlorinated n-alkanes in UK sewage sludge, survey results and implications, Environ. Sci. Technol. 37, 462-467.

Sumner, N.R.; Guitart, C.; Fuentes, G. \& Readman, J.W. (2010). Inputs and distributions of synthetic musk fragrances in an esturiane and coastal environment; a case study, Environ Pollut 158, 215-222.

Tanabe, S. (2005). Synthetic musks-arising new environmental menace? Mar Pollut Bull 50,1025-1026.

Ternes, T., 1998. Occurence of drugs in German sewage treatment plants and revers, Water Res. 32, 3245-3260

Topp, E.M; Metcalfe, C.D.; Li, H.; Gottschall, N.; Bolton, P.; Curnoe, W.; Payne, M.; Beck, A.,. Kleywegt, \& Lapen, D.R. (2009). Pharmaceutical and personal care products in tile drainage following surface spreading and injection of dewatered municipal biosolids to an agricultural field, Science of The Total Environment 407, 4220-4230.

Valdersnes, S.; Kallenborn, R. \& Sydnes, L.K. (2006). Identification of several Tonalide ${ }^{\circledR}$ transformation products in the environment, Int J Env Anal Chem 86, 461 - 471.

Watkinson, A.J.; Murby, E.J. \& Costanzo, S.D. (2007). Removal of antibiotics in conventional and advanced wastewater treatment: Implications for environmental discharge and wastewater recycling, Water Research 41, 4164-416

Watkinson, A.J.; Murby, E.J.; Kolpin, D.W. \& Costanzo, S.D. (2009). The occurrence of antibiotics in an urban watershed: From wastewater to dribling water, Science of The Total Environment 407, 2711-2723.

Wollenberger, L.; Halling-Sörensen, B. \& Kusk, K.O. (2000). Acute and chronic toxicity of veterinary antibiotics to Daphnia magna, Chemosphere 40, 723-730.

Wombacher, W.D. \& Hornbuckle, K.C. (2009). Synthetic musk fragrances in a conventional drinking water treatment plant with lime softening, J Environ Eng 135, 1192-1198.

Yang, S. \& Carlson, K. (2003). Evolution of antibiotic occurence in a river through pristine, urban and agricultural landscapes, Water Research 37, 4645-4656.

Zorita, S.; Måtensson, L. \& Mathiasson, L. (2009). Occurrence and removal of pharmaceuticals in a municipal sewage treatment system in the south of Sweden, Science of The Total Environment 407, 2760-2770. 


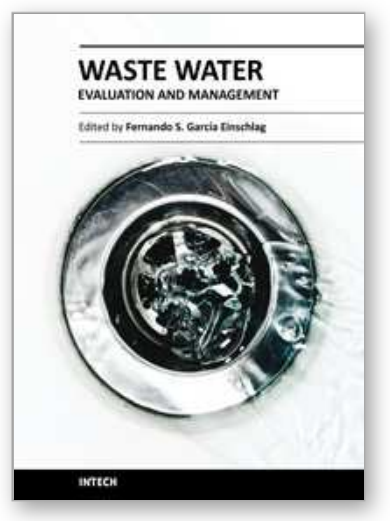

\author{
Waste Water - Evaluation and Management \\ Edited by Prof. Fernando Sebastĩ̃̃in GarcÃa Einschlag
}

ISBN 978-953-307-233-3

Hard cover, 470 pages

Publisher InTech

Published online 01, April, 2011

Published in print edition April, 2011

Fresh water resources are under serious stress throughout the globe. Water supply and water quality degradation are global concerns. Many natural water bodies receive a varied range of waste water from point and/or non point sources. Hence, there is an increasing need for better tools to asses the effects of pollution sources and prevent the contamination of aquatic ecosystems. The book covers a wide spectrum of issues related to waste water monitoring, the evaluation of waste water effect on different natural environments and the management of water resources.

\title{
How to reference
}

In order to correctly reference this scholarly work, feel free to copy and paste the following:

Helena Zlámalová Gargošová, Milada Vávrová, Helena Doležalová Weissmannová, Ludmila Mravcová, Lucie Vydrová and Libor Zouhar (2011). The Use of Methods of Environmental Analysis and Ecotoxicological Tests in the Evaluation of Wastewater, Waste Water - Evaluation and Management, Prof. Fernando Sebasti $\tilde{A}_{j} n$ GarcÃa Einschlag (Ed.), ISBN: 978-953-307-233-3, InTech, Available from:

http://www.intechopen.com/books/waste-water-evaluation-and-management/the-use-of-methods-ofenvironmental-analysis-and-ecotoxicological-tests-in-the-evaluation-of-wastewa

\section{INTECH}

open science | open minds

\section{InTech Europe}

University Campus STeP Ri

Slavka Krautzeka 83/A

51000 Rijeka, Croatia

Phone: +385 (51) 770447

Fax: +385 (51) 686166

www.intechopen.com

\section{InTech China}

Unit 405, Office Block, Hotel Equatorial Shanghai

No.65, Yan An Road (West), Shanghai, 200040, China

中国上海市延安西路65号上海国际贵都大饭店办公楼 405 单元

Phone: +86-21-62489820

Fax: $+86-21-62489821$ 
(C) 2011 The Author(s). Licensee IntechOpen. This chapter is distributed under the terms of the Creative Commons Attribution-NonCommercialShareAlike-3.0 License, which permits use, distribution and reproduction for non-commercial purposes, provided the original is properly cited and derivative works building on this content are distributed under the same license. 